\title{
Dealing with Dirty Deeds: Matching Nemo dat Preferences with Property Law Pragmatism
}

\author{
Donald J. Kochan*
}

\section{INTRODUCTION}

An organizing principle of the rule of law based on individualism and order is expressed by the Latin maxim nemo dat quod non habet (hereinafter nemo dat for shorthand) - roughly translated to mean that one can only give what they have or one can only transfer what they own. ${ }^{1}$ It is a matter of only being permitted to do what is within your legal authority to do. I should not be able to sell you a house after I sold it to someone yesterday (even if I at one earlier point owned the house) any more than I could sell you the Golden Gate Bridge (which I do not and never did own). My lack of authority in each should be the same. Once I have sold the thing I previously owned, my right to sell it should be irrevocably lost, and the property should no longer be mine to sell any more than selling something I never owned at all. This seems simple enough, but the law is seldom so easy. Markets never operate quite so mechanically, and sellers of real property sometimes behave badly (in other words, sell property twice or more) instead of behaving benignly and in compliance with the nemo dat limitations on what one should be allowed to do.

Instead of operating with a hammer when it comes to sales of

\footnotetext{
* Associate Dean for Research \& Faculty Development and Professor of Law, Chapman University Dale E. Fowler School of Law. I appreciate the valuable comments and suggestions offered by Daniel Bogart, Wilson Freyermuth, and Jennifer Spinella on early drafts of this work; and I thank Regina Zernay and Susan Nikdel for valuable research assistance.

1. See Black's Law Dictionary 1933 (10th ed. 2014) ("No one gives what he does not have; no one transfers (a right) that he does not possess. . . [N]o one gives a better title to property than he himself possesses."); see also Mitchell v. Hawley, 83 U.S. 544, 550 (1872) ("No one in general can sell personal property and convey a valid title to it unless he is the owner or lawfully represents the owner. Nemo dat quod non habet."). A related maxim is also relevant here: nemo plus juris ad alienum transferre potest quam ipse haberet, which means "no one can transfer to another a greater right than he himself might have." BLACK’s LAW DICTIONARY 1934 (10th ed. 2014).
} 
property without authority, the law tolerates some curious deviations from our expected or desired adherence to the nemo dat paradigm in order to advance other policies, including fairness and certainty of title. ${ }^{2}$ "Ownership" is more textured than one might immediately appreciate. With the aid of property recording acts, it becomes true that, in function, indeed one can sometimes sell more than they "own."

In this Article, the term "dirty deeds" shall take on two related meanings. One, it will represent those deeds (documents) that have been marked, or dirtied, by the first sale so that once they get to the second purchaser they are no longer clean and no longer entirely free for the taking. It shall also represent deeds (as in actions) that are disfavored, disagreeable, and harmful, against which we seek protection and deterrence to minimize their occurrence.

Consider the following example in which dirty deeds and nemo dat exceptions collide. In most jurisdictions, a grantor $X$ might sell Blackacre to person $Y$ and then later sell to person $Z$, and $Z$ might be awarded the title to the property so long as $Z$ is a bona fide purchaser without notice of the previous conveyance to $Y$ - even though $Z$ might take the land by what we could call a "dirty deed" (here used in the document form) - where the deed is soiled by its previous conveyance to $Y$ rather than being pure, clean, and fit for conveyance to $Z$; the deed seemingly represents property spoiled and incapable of being passed to others because it is already sold to another; and the deed is transferred

2. In an earlier work related to property recording laws, I focused my attention on deed traceability problems in recording associated with the mortgage foreclosure crisis and exacerbated by problems related to mortgage-backed securities and MERS. Donald J. Kochan, Certainty of Title: Perspectives After the Mortgage Foreclosure Crisis on the Essential Role of Effective Recording Systems, 66 ARK. L. REV. 267 (2013). That article also spent time developing some general background on the recording laws (without much discussion of the differences between types of recording statutes) and set forth a defense of the recording system itself as a vital facilitative component of a smooth functioning market system. Id. at 272-78. It spent particular time justifying the recording's place from a legal/political-philosophy perspective, articulating reasons why the state's role in recording is a necessary and essential foundational component of government even from a classical liberal or typically laissez-faire perspective. Id. at 298-311. In contrast, this Article does not deal with traceability of deeds and assignments nor does it implicate unique concerns associated with the mortgage and housing crisis. Instead, this Article carefully compares the types of recording statutes and types of notice. It then builds further support for the systematic importance of recording, but does so by dissecting the pragmatic deviations from the nemo dat principle facilitated by the bona fide purchaser exceptions to it in recording statutes. And, it analyzes the relative utility of these exceptions and presents a unique proposal for narrowing the frequency of access to those exceptions. Finally, this Article deals with a set of bad or irresponsible actors - those that fraudulently or mistakenly sell property multiple times-not evaluated in the previous work. Read together, however, both works contribute to a greater understanding of how the recording system works as a pragmatic tool, essential to markets in achieving the desirable ends of furthering certainty of title, security of ownership, traceability of deeds, and the smooth transfer of property at efficient values. 
through the dirty deed (here the phrase used in the action form) from $X$ who you would think should lack authority to sell Blackacre because he has already sold it to $Y$.

Despite this not uncommon scenario, it is nonetheless said that the principle in the nemo dat maxim underlies our title system and that its dictates usually hold true in the operation of land transactions. Yet we also know that the recording statutes calculatingly accommodate purposeful exceptions to the nemo dat principle as well, as in the example above. In other words, sometimes the law must ignore the nemo dat maxim in favor of other competing policy interests and pragmatic concerns in property law, namely certainty issues and the protection of bona fide purchasers. As in so many areas of property law, order matters but what one must do in what order is designed to accomplish specific ends.

Whereas strict adherence to nemo dat might be theorized as the "first-best" solution to fraudulent and recurrent land conveyances and best at adhering to our formalistic tendencies, the realities of property make that solution less than satisfactory and make exceptions justifiable. We have accepted pragmatically that exceptions must be made and that we may have to, in essence, validate fraud at times. ${ }^{3}$ Such validation will be a necessary evil when faced with two parties (the first buyer and the subsequent bona fide purchaser)—with relatively equal competing claims to innocence - that are vying for the same property yet where the law can declare only one winner in the contest.

This confrontation with such contests means that the law may need to be satisfied with "second-best" solutions to the "dirty deed" behavior. This Article briefly explores some of the second-best solutions we have to recurrent transfers of the same land, including incentivizing first takers to immediately record, civil lawsuits by the losers in the ownership choice against the dirty grantors, and criminal laws that protect society and are designed to deter these kinds of dirty deeds in the conveying of dirty deeds.

In Part II, this Article outlines the basic meaning and place of the nemo dat principle in our system of law. It then introduces the tensions between the ideal adherence to the maxim and the realities in the world that necessitate exceptions to (or a sometimes less-than-ideal

3. Audrey G. McFarlane, The Properties of Instability: Markets, Predation, Racialized Geography, and Property Law, 2011 WIS. L. REV. 855, 884 (2011) ("[T]here has been a social decision within property doctrine to sometimes ratify fraud-the basic issue of why $\mathrm{O}$ can pass property twice."). 
achievement of) the maxim. That introduction leads to Part III, which is intended to provide a valuable summary of the recording acts and their purposes, along with the types of notice and their uses, while exposing the tensions these recording systems each have with a strict notion of nemo dat. Part III will also do a comparative assessment of different types of recording regimes in light of these realities, identifying which are better at navigating these tensions.

Part IV returns to those tensions in detail and explains the purposes of the recording acts and why the protections for bona fide purchasers are necessary to facilitate markets in property and serve other goals. It reveals what might be called the impossibility of fully enforceable property rights in real property. It draws on case examples-where tough choices necessitate choosing certainty over protecting initially conferred "rights" - to reflect on why we make such choices. Part IV also explores the role of individual responsibility-particularly as it relates to purchaser obligations to record and examine records - as the core justification for setting the rules in a manner that may result in firstin-time titleholders sometimes losing out to subsequent purchasers.

Finally, Part IV concludes with a defense of the proposition that, despite our recognition of some exceptions from nemo dat, the law should constantly strive to develop in ways that can better approximate full adherence to a nemo dat ideal. This Article contends that we should structure our property law based on a preference for achieving the nemo dat ideal as closely as possible, understanding that pragmatism concerns do in fact make some exceptions necessary while also appreciating that we should find ways to minimize the need for invoking such exceptions and reduce the need to rely on such second-best solutions to dirty deeds. Without changing criteria for the exceptions, we can change the access to information and the speed of its flow to shrink the pool of those who fit the criteria for the bona fide purchaser exception. This would not be done by changing the nature of the protections available to innocent bona fide purchasers but instead by finding new ways to inject more information about land conveyances into the public view-beyond traditional recording mechanisms - so that more and earlier notice of possible competing property claims is available to responsible purchasers exercising due diligence.

To accomplish that goal, this Article concludes in Part V with one proposal that aims to take advantage of what I call the underexploited utility of "inquiry notice." The idea is to create better conditions to give first-in-time purchasers additional opportunities to protect their title interests by more easily triggering the inquiry obligations of second-intime and other subsequent purchasers. This Article outlines the 
components of a proposed new and innovative service that I call the "Title-Related Inquiry Notice Triggering System" (TINTS). As outlined, TINTS would operate in a manner that would provide a means for purchasers of property to protect their claim to title even earlier than official recording might accommodate. Taking advantage of modern technology with near-instantaneous uploading of information into the publicly available TINTS, purchasers can notify the world of the existence of their claim to a particular piece of property immediately upon the completion of a conveyance from the grantor. Through the development of custom, or perhaps by statutory mandate, it could become common practice for all purchasers to also access TINTS and search for potentially competing claims to the same property.

Part $\mathrm{V}$ acknowledges potential risks of abuse in such a system like TINTS that could themselves have market-disrupting effects. It offers some starting suggestions for controls against such risks, while explaining the market-facilitating benefits from a system like TINTS. In the end, we should find ways to strengthen the law's ability to make and defend the claim more frequently that one truly cannot sell what they have previously sold. TINTS, or other innovations like it, can assist us in matching these nemo dat preferences with property law pragmatism. Maximizing the consonance of outcomes in real world title contests with the nemo dat ideal should be a goal of the property system.

\section{A BRIEF INTRODUCTION TO THE NEMO DAT PRINCIPLE AND ITS PLACE IN REAL PROPERTY LAW}

As stated at the top of this Article, the Latin maxim nemo dat quod non habet - one cannot give what they do not have (or, you have to have it to give it ${ }^{4}$-holds a special place in our law. The nemo dat principle is so strong that it has broad applications associated with the transfer of most assets, not just real property. ${ }^{5}$

4. See BlaCK's Law Dictionary 1933 (10th ed. 2014) ("No one gives what he does not have ...."); Kevin E. Davis, The Effects of Forfeiture on Third Parties, 48 MCGILL L.J. 183, 19697 (2003) (articulating the "common law rule of nemo dat quod non habet ("he who hath not cannot give')").

5. See, e.g., Stephen T. Black, Psst! Wanna Buy a Bridge? IP Transfers of Non-Existent Property, 31 GA. ST. U. L. REV. 523, 529-30 (2015) (discussing the broader applications of nemo dat-like norms); Adam J. Levitin, Finding Nemo: Rediscovering the Virtues of Negotiability in the Wake of Enron, 2007 Colum. Bus. L. REv. 83, 90 (2007) [hereinafter Levitin, Finding Nemo] (defining "the commercial law principle of nemo dat quod non habet-you can transfer only what you have") (emphasis added); Carl S. Bjerre, Secured Transactions Inside Out: Negative Pledge Covenants, Property and Perfection, 84 CoRnELl L. REv. 305, 333 (1999) ("[I]f the owner grants a security interest to one lender, the nemo dat principle standing alone would dictate that the owner 
We should strive for the nemo dat ideal. It is principled, in line with respect for autonomy and the promotion of individualism, better situated within rule of law concepts and the limits of individual authority, rewards honesty, protects the integrity of the legal system, promotes the legitimacy of the system, and prevents bad actors and fraud (including preventing such actors' unjust enrichments). The principle preserves the sanctity of ownership, and it minimizes the effectiveness of dirty deeds perpetrated through fraudulent, scoundrelous, or predatory behavior. ${ }^{6}$ We feel more secure in our property holdings if we believe that no one can take them away. ${ }^{7}$

Frankly, and perhaps most importantly, applying nemo dat makes true the rewards due to those who are first in time. A strong nemo dat regime effectuated by more information making its way into the system protects first-in-time purchasers who gave good and valuable consideration to purchase the property and who thought that by doing so they could "own" it thereafter in exclusion of all others. We should find a way to make those deals stick when we can. The proposal at the end of this Article seeks to find one way that the law can aim to meet that charge with innovative experimentation with new ways to strengthen the network of information available to all players in the property title system so that deviations from nemo dat might be minimized.

Nemo dat makes sense, ${ }^{8}$ and the strength of our intuitions regarding nemo dat explains why many are so flummoxed when you inform them that a person can sell you a piece of property today that yesterday he sold to your neighbor. ${ }^{9}$ It seems counterintuitive, as if it violates basic principles we learned as far back as kindergarten regarding scarcity and

may not thereafter grant a security interest of the same or greater priority to a later lender.") (emphasis added); Adam J. Levitin, The Paper Chase: Securitization, Foreclosure, and the Uncertainty of Mortgage Title, 63 DuKE L.J. 637, 700 (2013) [hereinafter Levitin, The Paper Chase] ("Under the basic commercial-law rule of nemo dat, a transferor cannot transfer rights it does not have; I cannot sell you the Brooklyn Bridge.") (emphasis added).

6. See McFarlane, supra note 3, at 885 (identifying those who engage in conveying property twice as "predators").

7. Thomas E. Plank, Article 9 of the UCC: Reconciling Fundamental Property Principles and Plain Language, 68 BUS. LAW. 439, 441-42 (2013) ("[T]he principle that one cannot transfer an interest in property that the transferor does not have . . . [P]romotes the security of property."); see also Steven L. Harris \& Charles W. Mooney, Jr., U.C.C. Article 9, Filing-Based Priority, and Fundamental Property Principles: A Reply to Professor Plank, 69 Bus. LAW. 79, 80-81, 87-88 (2013) (discussing nemo dat).

8. Bjerre, supra note 5, at 333 ("The principle has strongly intuitive justificatory force; even children understand the power of the righteous claim, 'I had it first!'”).

9. Ralph W. Aigler, The Operation of the Recording Acts, 22 MicH. L. REV. 405, 416 (1924) (discussing how it baffles some that the grantor (or a grantor's heir) retains "a power to defeat the unrecorded deed" that he himself granted). 
ownership. $^{10}$

Do the exceptions to nemo dat also make sense? To a degree, I think the answer is a clear yes. But those exceptions require more explanation, especially because they must overcome this intuitive, common sense belief $^{11}$ that no one should be able to sell the same thing twice. The application of nemo dat, however, cannot in modern law be divorced from the necessity of standards for setting priorities between multiple innocent claimants rather than simply applying a priority-by-time-ofconveyance rule. $^{12}$

The next Part will give readers the background necessary to understand how the law has come to develop these recording and title priority rules. The rules discussed are normally just referred to as basic rules of recording real property interests. Yet these rules take on a new meaning and understanding if they are framed as exceptions to, and pragmatic tools for the management of, the nemo dat principle and as considered deviations away from the nemo dat preference.

\section{BACKGROUND: BASIC TERMINOLOGY AND DOCTRINE FOR RECORDING ACTS AND NOTICE MECHANISMS}

Before reaching the heart of this Article's assessment of the reasons to adhere to a nemo dat principle and the reasons for its exceptions, this Part will provide some basic terminological and doctrinal background to orient the reader to the various types of recording statutory regimes and how they operate. Most of the discussion regarding why these systems operate as they do and the purposes of recording will be saved for later Parts in this Article. For now, the purpose will be to make sure all readers have a basic understanding of the recording system and the types of notice recognized by the law within that system.

10. Cf. generally Robert Fulghum, All I Really NeEd to Know I Learned in KinDERGARTEN 6 (1988) ("Don't take things that aren't yours.").

11. Henry E. Smith, On the Economy of Concepts in Property, 160 U. PA. L. REv. 2097, 2120 (2012) (stating that the nemo dat principle "sounds like common sense, and it is").

12. Davis, supra note 4, at $196 \mathrm{n} .67$ ("[N]emo dat rule is merely a priority rule ...."); see also Levinz v. Will, 1 Dall. 430, 433-34 (Pa. 1789) (evaluating early act requiring recording of mortgage within six months in order to be effective against mortgagor and discussing the fact that "in the case of an innocent purchasor without notice of a previous conveyance ... there may be circumstances which place him in a more favorable point of view" and explaining that recording statutes reflect that concern). 


\section{A. Types of Recording Statutes}

When two or more individuals make claim to the same piece of property, rules must be established to resolve these competing claims. The following sections will evaluate four basic types of jurisdictional approaches to this problem: (1) no recording statute and instead where common law principles of first-in-time prevail; (2) "race" recording statutes; (3) "notice" recording statutes; and (4) "race-notice" statutes. ${ }^{13}$ In each of these cases, we are concerned with a competing claimant other than the grantor, i.e. two different purchaser-grantees. Because a grantor and grantee are parties to their own conveyance, their respective rights vis-à-vis each other will be judged by the terms of the conveyance. Resolution of competing claims between those parties will be resolved based on the documents and circumstances surrounding their transaction rather than on the recording rules of the jurisdiction. An unrecorded deed is still valid and binding as between those parties to a conveyance of the property (and does so even in the face of statutory language that appears to claim only recorded deeds are "valid" because, under those statutes, the validity is being judged only with regard to subsequent purchasers). ${ }^{14}$ This Article's major concern lies outside that initial relationship and instead focuses most of its attention on disputes between multiple purchasers claiming to hold title to the same property.

Today, all states have some type of recording act and none rely on common law rules alone for the priorities between successive purchasers. ${ }^{15}$ Very few states use pure race rules, ${ }^{16}$ while the remainder

13. On each of the types of recording regimes, including first-in-time and no recording act, see Joseph William Singer, Property $\$ 11.4 .5 .2$ (3d ed. 2010); 1 JoyCE PALOMAR, PATTON AND PALOMAR ON LAND TITLES $§ 5$ (3d ed. 2003) (dedicating treatise section to comparing recording acts); see also John H. Scheid, Down Labyrinthine Ways: A Recording Acts Guide for First Year Law Students, 80 U. DET. MERCY L. REV. 91, 106-10 (2002) (describing the basics of the recording acts and notice requirements and rules); Michael Palestina, Comment, Of Registry: Louisiana's Revised Public Records Doctrine, 53 LOY. L. REV. 989, 1000-02 (2007) (describing the recording systems and notice requirements).

14. See 5 Herbert Thorndike Tiffany, The LAw of ReAl Property $§ 1262$ (3d ed. 1939 \& Supp. 2004) (failing to record only affects subsequent purchaser and "a failure to record the instrument in no way affects the passing of title as between the parties thereto" even when a statute "provides that a deed of real property shall not be valid for purpose of passing title unless it is acknowledged and recorded as directed by the statute").

15. See Charles Szypszak, Real Estate Records, The Captive Public, and Opportunities for the Public Good, 43 Gonz. L. REV. 5, 24 (2007-2008) [hereinafter Szypszak, Real Estate Records] ("All states have . . laws that govern the effect of recording ....").

16. See SINGER, supra note 13, § 11.4.5.2, at 541 n.308. See also Szypszak, Real Estate Records, supra note 15, at 26 (stating only three states have pure race statutes). 
are about equally mixed between notice and race-notice rules. ${ }^{17}$ The following sections will highlight the differences between the recording regimes, but as these and later sections reveal, the jurisdictional interpretation and application of recording rules are more uniform (at least across the notice and race-notice jurisdictions) than they may originally seem, especially regarding the lack of protections for purchasers with notice. ${ }^{18}$

\section{No Recording Statute/Common Law}

Under the common law, priority was dealt with through the simple application of first in time, first in right. ${ }^{19}$ So, before recording acts displaced the common law priority rules, disputes between two claimants to title at common law were resolved by simple first-in-time rules and "[i]f an owner purports to make two conveyances of the same land, the earlier one will prevail ...."20 The second purchaser, even if they had no notice of the prior claim, ${ }^{21}$ loses and at best can sue the grantor under warranties or perhaps for fraud. ${ }^{22}$

In this sense, the protection of the first-in-time claimant and the refusal to give effect to a subsequent conveyance of the same property comported with the nemo dat ideal. While a grantor may try to sell the

17. Jerry L. Anderson \& Daniel B. Bogart, Property Law: Practice, Problems, and PERSPECTIVES 541 (2014) (discussing the distribution of recording statute types); Emily BayerPacht, Note, The Computerization of Land Records: How Advances in Recording Systems Affect the Rationale Behind Some Existing Chain of Title Doctrine, 32 CARDOZO L. REV. 337, 344 n.50 (2010) ("Approximately half of the states now have notice statutes and the other half have race-notice statutes.").

18. See 1 PALOMAR, supra note $13, \S 5$ ("' $[\mathrm{R}]$ ecording acts of the several states show a general uniformity, in spite of differences in phraseology.... [J]udicial decisions have a greater uniformity than the acts themselves and indicate that the differences in the acts are more apparent than real."); Gerald Korngold, Resolving the Intergenerational Conflicts of Real Property Law: Preserving Free Markets and Personal Autonomy for Future Generations, 56 AM. U. L. REv. 1525, 1564 (2007) [hereinafter Korngold, Resolving] ("While the recording acts differ among the states in some respects, they share many common models, attributes, and goals."); Szypszak, Real Estate Records, supra note 15, at 24 ("Most of the states' [recording] laws share the same essential features, which take into account both the order of recording and any notice a claimant may have had about a prior, competing conveyance.").

19. John W. Fisher, II, The Scope of Title Examination in West Virginia: Can Reasonable Minds Differ?, 98 W. VA. L. REV. 449, 453 (1996) (describing first-in-time principles to resolve conflicting claims to land "in feudal England, [when] there were no recording laws").

20. See SINGER, supra note 13, § 11.4.5, at 541.

21. Sue Ortman, Comment, USLTA: Marketable Record Title Act-A New Title Theory and Its Effect on Texas Law, 12 ST. MARY'S L.J. 462, 465 (1980) (“The common law doctrine of 'first in time, first in right' encouraged fraudulent conveyances of real property and worked a hardship on subsequent purchasers unaware of the earlier conflicting interest.").

22. See id. 
same property twice and commit fraud, such second sale will not have legal effect and will not subordinate the first purchaser's rights to the property.

It is precisely the possibility of fraud and the way it was encouraged under these common law rules - because there was no definitive records office to verify claims, requiring multiple claimants to expend money proving their case for priority based on developing an evidentiary record that they were first in time - that led to substantial criticism of the system and motivated the adoption of recording laws as providing more effective verifiability systems. ${ }^{23}$ Without recording provisions and effect given to the act of recording, individuals were easily duped into buying property that had already been sold to another because there was no way to check and verify the existence or non-existence of competing claims. The move toward recording regimes was designed, in part, to resolve that issue of undetectability. ${ }^{24}$

Recording helps provide evidence of a superior claim to the world, or at least helps define the meaning of "superior" in a manner accompanied with mechanisms to verify that priority. Recording is the method by which modern purchasers vaunt their claim to newly conveyed property and serve public notice, which takes the place of less transparent and verifiable means of proof. ${ }^{25}$

With the passage of recording acts, the states have replaced the common law priority rules with laws that require either some step beyond conveyance or, at the very least, an additional metric of notice to come into play before determining which grantee receives priority in a title contest. ${ }^{26}$ In other words, in every state in the United States, it is now usually no longer enough to simply be the first party to be conveyed property in order to win in a title contest. ${ }^{27}$ Of course, in those situations where recording acts exist but no claimants (original or subsequent) take advantage of them-i.e. when neither party can fit into the safe harbor that a recording system typically provides - the parties are defaulted

23. Id. at 463 ("To meet the needs of today's urban, highly mobile society, a land transfer system must provide for simple, secure, and inexpensive transfers.").

24. Charles Szypszak, North Carolina's Real Estate Recording Laws: The Ghost of 1885, 28 N.C. CENT. L.J. 199, 200 (2006) [hereinafter Szypszak, North Carolina] (stating recording laws work to protect purchasers against "undetectable competing claims").

25. See 1 PALOMAR, supra note $13, \S 17$ ("The record of a deed today serves the same function of public notice as did livery of seisin and the delivery of a twig, clod or key in former times.").

26. See 5 TIFFANY, supra note 14, $\$ 1262$ (describing how recording acts preempt prior firstin-time common law rules).

27. See Szypszak, Real Estate Records, supra note 15, at 24 (describing the resolution of conflicting claims under no recording statute and then under each of the existing recording regimes). 
back into a first-in-time resolution of a title dispute.

Without a recording system, a purchaser would be entirely dependent on the assurances of the vendor of the property - a situation that is rife with the potential for abuse. ${ }^{28}$ After all, what incentive would there be for a vendor to disclose the existence of prior competing interests? The recording system seeks to provide an institutional correction and a market-enhancing mechanism to defeat those temptations to commit such dirty deeds. A primary purpose of recording is to create official public records that protect buyers "against any competing claims that may be created by the grantor in others" ${ }^{\prime 29}$ and to influence the behavior of owners (and their lawyers and other representatives) in a way that motivates the creation and transaction of title that is as clean as possible.

The next subsections outline the three jurisdictional models adopted in various states. Through application of each of these recording acts in their own way, it can be said that particular individuals will "win" in some contests based on operational exceptions to the nemo dat principle. All of the recording acts at least diminish the nemo dat principle's power as a controlling influence in title disputes.

\section{Race Jurisdictions}

In the very few jurisdictions that have chosen to operate under a "race" statute, the idea is simple: when there are two competing successive purchasers of a particular piece of property, the first to record his interest is awarded the property because he has won the race to the recording office. ${ }^{30}$ To see how a race statute is typically worded, consider the following language from the recording laws of North Carolina:

$\S 47-18$. Conveyances, contracts to convey, options and leases of land

28. The U.S. Supreme Court explained these perverse incentives in its Neslin $v$. Wells opinion:

To hold otherwise would be to declare that land should cease generally to be the subject of sale; for no amount of diligence on the part of a purchaser would insure his title. He would, of course, demand of the vender an inspection of his title-deeds. From them he would learn the chain of title. A production and examination of the deeds made in the common form would show by their recitals that none of the preceding owners could have any claim for unpaid purchase-money, for the receipt of it, in each instance, is usually contained in the deed. He would, therefore, reasonably deem it unnecessary to make any personal inquiry, and in respect to supposed incumbrances in favor of strangers he would be compelled to rely upon the statements of the vendor.

Neslin v. Wells, 104 U.S. 428, 436 (1881).

29. SINGER, supra note $13, \S 11.4 .5 .1$, at 538.

30. See Szypszak, Real Estate Records, supra note 15, at 24-25. 
(a) No (i) conveyance of land, or (ii) contract to convey, or (iii) option to convey, or (iv) lease of land for more than three years shall be valid to pass any property interest as against lien creditors or purchasers for a valuable consideration from the donor, bargainor or lessor but from the time of registration thereof in the county where the land lies, or if the land is located in more than one county, then in each county where any portion of the land lies to be effective as to the land in that county. Unless otherwise stated either on the registered instrument or on a separate registered instrument duly executed by the party whose priority interest is adversely affected, (i) instruments registered in the office of the register of deeds shall have priority based on the order of registration as determined by the time of registration, and (ii) if instruments are registered simultaneously, then the instruments shall be presumed to have priority as determined by:

(1) The earliest document number set forth on the registered instrument.

(2) The sequential book and page number set forth on the registered instrument if no document number is set forth on the registered instrument.

The presumption created by this subsection is rebuttable. ${ }^{31}$

Race jurisdictions can be characterized as "survival of the fastest" regimes, where the party first to the courthouse survives in his claim regardless of the quality of the claim itself at least vis-à-vis other claimants. Some paint race jurisdictions in a positive light, highlighting that the legislative choice made under such laws fosters much-valued greater certainty. ${ }^{32}$ One could also make a claim that race statutes reward those with the greatest demonstration of individual responsibility, coupled with competitive edge by laboring harder, faster, and in accordance with the established rules of the game to reach the recording office first.

In pure race jurisdictions, ${ }^{33}$ it is a matter of priority by record alone. Certainty and efficiency-combined with a judgment that those who protect their interests most speedily and diligently, contributing to the completeness of information in the records-set the policy in such jurisdictions. In contrast, equitable concerns over protecting subsequent

31. N.C. Gen. Stat. ANN. § 47-18(a) (West 2013).

32. See, e.g., Dep't of Transp. v. Humphries, 496 S.E.2d 563, 566 (N.C. 1998) ("The purpose of these laws is to provide certainty in real estate transactions, for the benefit of purchasers and lenders.").

33. Race jurisdictions are often termed "pure race" jurisdictions so as not to be confused with race-notice jurisdictions. See Szypszak, Real Estate Records, supra note 15, at 24-25. 
purchasers without notice are valued less in pure race jurisdictions. ${ }^{34}$ Neither time of conveyance nor whether either party had notice of the other party matters in a pure race jurisdiction. ${ }^{35}$ Thus, even a second purchaser who knows of the first purchaser can prevail. ${ }^{36}$ For this reason, some see pure race as unfair, explaining also the popularity of the other two regimes: notice and race-notice. ${ }^{37}$ In contrast to pure race regimes, the idea behind notice and race-notice alternatives is to protect bona fide purchasers who take from grantors and, by no fault of their own, have no idea that another party has been previously sold the property. ${ }^{38}$ On the other side of the coin, another related purpose is to avoid rewarding later purchasers who know the grantor has already sold the same property to someone else. ${ }^{39}$ In other words, these other models protect a bona fide purchaser for value and without notice-someone who has no reason to question the authority of his grantor to sell the property in question ${ }^{40}$ - while race is indifferent to such a complexion.

The recording laws have developed in most jurisdictions under models that care about such purchaser characteristics. ${ }^{41}$ With slight variation between them, these two notice-based models shield those later purchasers who have an honest belief in the legitimacy of the real property transaction to which they become a party, ${ }^{42}$ as the next two subsections detail in turn.

34. See, e.g., ANDERSON \& BOGART, supra note 17, at 542 ("[R]ace statutes value certainty over fairness," promoting the idea that by "fair" we mean protecting subsequent purchasers without notice).

35. See id. at $542-43$.

36. Id.

37. SINGER, supra note $13, \S 11.4 .5 .2$, at 542 (discussing the inequities in race statute regimes where it allows "later buyers to prevail over earlier buyers when they know about the earlier conveyance" that notice and race-notice attempt to correct).

38. See Hutchinson v. Harttmann, 15 Kan. 133, 141 (1875) (defining bona fide purchaser); Cunningham v. Norwegian Lutheran Church of Am., 184 P.2d 834, 836-37 (Wash. 1947) (upholding basic protections for bona fide purchasers) (citing Kroetch v. Hinnenkamp, 18 P.2d 491, 492 (Wash. 1933)).

39. See Szypszak, Real Estate Records, supra note 15, at 25.

40. Chad J. Pomeroy, Ending Surprise Liens on Real Property, 11 NEV. L.J. 139, 142 n.12 (2010) (describing the broad meaning of "bona fide purchaser for value" as "derivative of the common law concept of one who gains an interest in property for fair value and in good faith believing the seller possessed full rights to the transferred property interest").

41. See Szypszak, Real Estate Records, supra note 15, at 24-25.

42. Beach v. Faust, 40 P.2d 822, 823 (Cal. 1935) ("The recording laws['] . . purpose is to protect those who honestly believe they are acquiring a good title, and who invest some substantial sum in reliance on that belief."). 


\section{Notice Jurisdictions}

Pure notice jurisdictions ${ }^{43}$ focus on just that-notice. ${ }^{44}$ In a pure notice jurisdiction, a subsequent purchaser who takes a property without notice of the prior claimant will win, in essence, invalidating or subordinating the rights of the prior grantee. ${ }^{45}$ Some phrase the notice jurisdiction rules as meaning this result occurs regardless of who records first, and that phrasing has some merit. ${ }^{46}$ But, while that may be technically true, it is always the case that if the first grantee records before the conveyance to the subsequent grantee, then the subsequent grantee will be on record notice of the prior grantee and will not be in a position to invalidate the prior grantee's claim. ${ }^{47}$ In other words, if the subsequent grantee has notice-record or otherwise-of the earlier conveyance then that subsequent grantee cannot take priority.

A typical notice jurisdiction will have language in its recording act similar to that used in Kansas: "No such instrument [conveying or affecting real estate] in writing shall be valid, except between the parties thereto, and such as have actual notice thereof, until the same shall be deposited with the register of deeds for record." 48 Recording itself ensures that all parties will have notice of the pre-existing claim and cannot claim to be without notice. ${ }^{49}$ But until title is recorded, so long as a subsequent purchaser is without "actual notice" (which is a term that Kansas and other jurisdictions have generally interpreted quite broadly to include actual, implied, constructive, record, and inquiry notice ${ }^{50}$ ) of the

43. Notice jurisdictions are sometimes referred to as "pure notice" jurisdictions so as not to be confused with race-notice jurisdictions. See Szypszak, Real Estate Records, supra note 15, at 28.

44. See id. at 27.

45. Id.

46. See id. at 26-27 (explaining notice jurisdiction rules).

47. See infra Part III.B.

48. KAN. StAT. ANN. § 58-2223 (2008). This section is titled "[Recordation of instruments conveying or affecting real estate]; unrecorded instrument valid only between parties having actual notice." See also Mo. REV. STAT. § 442.400 (2000) ("No such instrument in writing shall be valid, except between the parties thereto, and such as have actual notice thereof, until the same shall be deposited with the recorder for record."). It should be noted that the word "deposited" here identifies the point of legal effectiveness for certain purposes but not all. See infra Part V. This is because subsequent purchasers sometimes will not be charged with knowledge of the recording until it is both deposited and thereafter indexed and recorded in a manner that makes the deed capable of being found through a diligent search of the records in the records office. Id. Cases dealing with delays and misindexing often raise complex, fact-specific issues and differential treatment across jurisdictions that are beyond the scope of this Article.

49. See infra Part III.B.

50. See, e.g., Faris v. Finnup, 113 P. 407, 408 (Kan. 1911) ("Actual notice may be either express or implied; that is, it may consist of knowledge actually brought personally home, or it may consist of knowledge of facts so informing that a reasonably cautious person would be led by them 
previous conveyance, then that conveyance is not valid to enforce against that subsequent purchaser and the subsequent purchaser wins because he is a bona fide purchaser without notice. ${ }^{51}$

If, however, the subsequent purchaser has notice of the previous conveyance, then the import of the language is that the prior conveyance will be valid for the earlier grantee to assert against the subsequent grantee to defeat the later-in-time conveyance in a contest for ownership of the property. Note again, however, that even though the first grantee is not required to record first in order to prevail in such a contest with a subsequent purchaser, it is absolutely prudent that the first purchaser records even in a pure notice jurisdiction. This is because, by doing so, he effects notice on the entire world, including the full pool of potential subsequent purchasers, thereby defeating all claims by subsequent purchasers who then cannot be eligible for the label of "bona fide" once record notice exists. It is precisely this reality that makes notice jurisdictions usually indistinguishable operationally from race-notice jurisdictions, because in the vast majority of cases the first purchaser in notice jurisdictions will also be both a purchaser without notice of competing claims and the first to record.

\section{Race-Notice Jurisdictions}

Race-notice jurisdictions seek to combine the best of both race and notice jurisdictions to achieve an efficient and predictable, yet also fair, result. $^{52}$ Under a race-notice regime, a subsequent purchaser faces a tough set of hurdles. A subsequent purchaser can only get priority status over prior grantees if he both (1) takes his conveyance without notice of the other claimants and (2) is the first to record his claim. ${ }^{53}$ Even after

to the ultimate fact.").

51. Nuckles v. Tallman, 187 P. 654, 655 (Kan. 1920) (explaining unrecorded deeds under Kansas statutes are valid between the parties to that deed, to those with actual notice of the deed, and otherwise "to be given full force, except as against the claims of innocent purchasers for value, or persons having equities of substantially equal strength").

52. ANDERSON \& BOGART, supra note 17, at 546 (explaining race-notice statutes "combine the critical elements" of race and notice approaches); SINGER, supra note 13, § 11.4.5.2, at 543-44 ("Race-notice laws represent a compromise between the predictability of race statutes and the fairness of protecting only those who buy without notice of the prior claim.").

53. Szypszak, Real Estate Records, supra note 15, at 27; 5 TIFFANY, supra note 14, $§ 1258$ (describing the favored status of legal title as actual owner over holder of a mere equitable title interest); Schwalm v. Deanhardt, 906 P.2d 167, 169-70 (Kan. Ct. App. 1995). "Actual notice" in Kansas is express or implied and includes those things to which "a reasonably cautious person would be prompted to further inquiry, which further inquiry would inform him of the outstanding unrecorded conveyance." Id. (citing Lane v. Courange, 359 P.2d 1115, 1118 (Kan. 1961)). "[A]ctual notice includes knowledge of circumstances to enable reasonably prudent persons to 
the property is sold to a second purchaser without notice, the first purchaser (so long as he also had no notice of competing claims at the time of his purchase (which is subsumed if he is truly "first")) still has a window to perfect his claim to title by recording before (and winning the race with) the subsequent purchaser. ${ }^{54}$

California's recording statute provides a good example of terms used to create a race-notice system:

Every conveyance of real property or an estate for years therein, other than a lease for a term not exceeding one year, is void as against any subsequent purchaser or mortgagee of the same property, or any part thereof, in good faith and for a valuable consideration, whose conveyance is first duly recorded, and as against any judgment affecting the title, unless the conveyance shall have been duly recorded prior to the record of notice of action.

In essence, race-notice jurisdictions protect those that are first to file so long as they are without notice of prior purchasers. ${ }^{56}$

Consider the following example application. If the subsequent purchaser $D$ takes without notice on Tuesday, then the earlier purchaser $C$ (who was also without notice of competing claims) records on Wednesday, then the subsequent purchaser $D$ records on Thursday, the result is that the subsequent purchaser $D$ is too late in a race-notice jurisdiction. Despite his "innocence"-i.e. lack of knowledge or notice of the earlier claimant $-D$ was not quick enough, and $D$ loses. Note that in a pure notice jurisdiction, however, $D$ would have won under the above facts (because he took without notice, including without record notice because at the time $D$ purchased $C$ still had not yet recorded). In order for $D$ to win in the facts above, he would have needed to record sometime before $C$.

$$
* * *
$$

As mentioned above, despite variations in the language of some

investigate and ascertain the ultimate facts." Id. at 170.

54. See William A. Reppy, Jr., Some Issues Raised by Alaska's Recording Act, 27 ALASKA L. Rev. 195, 198 (2010). Professor Reppy explains it this way:

Under a Notice-type statute, as soon as the second-in-time deed is delivered to a bona fide purchaser, the prior grantee who had yet to record is divested of his or her title that conflicts with the grant to the subsequent purchaser. But under a Race-Notice statute, title remains in the first grantee until the subsequent bona fide purchaser records. Thus, the prior grantee is only divested if the subsequent purchaser actually records. Id. at 197.

55. CAL. CIV. Code $\S 1214$ (West 2007). The title of this section is "Prior recording of subsequent conveyances, mortgages, judgments."

56. Id. 
recording statutes, they (except for race jurisdictions) "almost invariably... have received the same construction, as affording protection to a subsequent purchaser only when he is without notice of the unrecorded conveyance." 57 Under all of these variations on establishing priority, if a first-in-time purchaser acts responsibly and records, most often he will be protected. ${ }^{58}$ Of course prudence dictates that one should immediately record, yet that may not be enough protection in every case. There may be gaps between the filing of a record and its effectiveness in the recording office that must be addressed and these are some of the concerns addressed later in this Article. ${ }^{59}$

Nonetheless, the vast majority of interests can be protected against adverse claims by prompt recording no matter what jurisdictional rules apply-whether it is to win the race, to use the recording to provide notice, or to both provide notice and beat others (who are without notice) in a race to the perfection of one's title. Once the first grantee files and creates record notice, he is protected against subsequent purchasers under both notice and race-notice regimes because all others will be put on notice of the competing claim ${ }^{60}$ and therefore will be unable to meet the standards to be an eligible bona fide purchaser without notice ${ }^{61}$ (and, consequently, will usually lose in a contest with a prior title claimant ${ }^{62}$ ).

Once title is recorded, the prior owner's ability to successfully carry out a fraudulent re-conveyance without exposure and liability is severely diminished. This fraud-deterrence function is at least one rationale underlying the development of recording laws and bona fide purchaser protections. ${ }^{63}$ The process of recording should capture and prevent most multiple sales from subordinating the first-in-time purchaser. ${ }^{64}$ Nonetheless-whether it is because of errors in recording, gaps in

57. 5 TIFFANY, supra note $14, \S 1283$.

58. See id.

59. See infra Part V.

60. Neslin v. Wells, 104 U.S. 428, 433 (1881) ("It is a mere corollary from this datum that these records are, by construction of law, notice to all persons of what they contain.").

61. Poplin v. Mundell, 27 Kan. 138, 156 (Kan. 1882) (acknowledging effects of record notice on subsequent purchasers).

62. See Dan S. Schechter, Judicial Lien Creditors Versus Prior Unrecorded Transferees of Real Property: Rethinking the Goals of the Recording System and Their Consequences, 62 S. CAL. L. REV. 105, 116-17 (1988) (discussing relative cost avoidance and explaining that when we assume that a subsequent purchaser had "notice of the prior unrecorded interest, it follows that he could have avoided the problem" by informing himself and thereafter refusing to purchase "but failed to do so").

63. Id. at 112 ("[T]he fraud deterrence rationale partly explains why relying classes of subsequent transferees would be protected, while the certainty rationale partly explains why some unrecorded transfers not involving fraud are nevertheless invalidated.").

64. See id. at 118. 
recording time, failure of purchasers to know that it is necessary and prudent to record, or other failure - subsequent purchaser subordination of prior title claimants is a real phenomenon. ${ }^{65}$ That means that exceptions to nemo dat are not simply theoretical but instead exist and operate, in fact, to empower the passing of dirty deeds.

Similarly, if you act responsibly and do your due diligence as a purchaser, becoming informed of any potential adverse claims and finding none, then in most cases, you will be protected by the shelter provided to bona fide purchasers without notice. If you find an adverse claim, then you will most likely breathe a sigh of relief as you avoided purchasing an encumbered title. A purchaser who fails to check the records before buying land, though, acts negligently and has no excuse $^{66}$ - he is charged with knowledge of all things contained and discoverable in the property records. ${ }^{67}$ Of course, depending on the jurisdiction, every purchaser who thinks he could potentially be a subsequent purchaser (a fear that every purchaser should force himself to have) may need to record promptly as well to get that recording law protection. No matter what your position in the sequence or what recording model applies, one cannot escape the reality that thorough title history homework and prompt title recording are both necessities in any land acquisition.

Legislatures set the recording rules for society to follow and within those statutes provide means for all parties to protect themselves. The recording statutes set standards by which courts can interpret obligations and compliance with such rules to decide between competing claimants to title. Once the rules are set, it is the individual's responsibility to understand the legal system and operate within it, including, for example, for a purchaser to understand that recording is essentially a duty; but certainly, at the very least, a purchaser must understand that recording is a prerequisite to receiving the full protection of the law.

Of course, notice is the key because even if a prior conveyance is unrecorded, a subsequent purchaser who actually knows about the prior conveyance or is given reason to inquire in a way that they would learn

65. Id. at 126

66. Bankers Trust Co. v. United States, 25 P.3d 877, 881 (Kan. Ct. App. 2001) (““[I]t is negligence for a purchaser of either real or personal property to make the purchase without ascertaining the facts shown by the records which may affect the title to be acquired." (quoting Kuhn v. Nat'l Bank of Holton, 87 P. 551, 552 (Kan. 1906))).

67. Kuhn v. Nat'l Bank of Holton, 87 P. 551, 552 (Kan. 1906) (“[P]urchaser will be presumed to have bought with knowledge of all the facts which the records at the time would have disclosed. Equity cannot be invoked to relieve one from the consequences of his own negligence." (citing Hargis v. Robinson, 66 P. 988, 988-89 (Kan. 1901))). 
about it typically lacks the ability to "win" in a battle for the property over the prior grantee. ${ }^{68}$ Given how critical notice becomes to the operation of the recording system and the identification of priority between competing claims, this Part will close with some introductory background on the types of notice recognized by the law as defeating one's ability to claim status as a subsequent bona fide purchaser.

\section{B. Background on Types of Notice}

If you know or should know that a grantor lacks or might lack the authority to sell you a piece of property, then you cannot claim to be innocent in the possible perpetuation of fraud by the grantor. ${ }^{69}$ It is a matter of equity, always (both before, after, and irrespective of any existing notice or race-notice recording acts), that one with notice of an adverse claim purchases without the good faith necessary to give that purchaser the legal status surrounding the term "bona fide purchaser." Although this status is more formally sometimes referred to as "bona fide purchaser for value" or "bona fide purchaser for value and without notice" or "bona fide purchaser without notice," this Article will mainly use "bona fide purchaser" as shorthand for these longer terms that mean essentially: to be entitled to protection under notice and race-notice recording acts, the purchaser is one who buys the property, for a real, non-sham value, is not engaged in fraud, and has no notice that something is not quite right with the sale. ${ }^{71}$ This Article's concern is principally on the "notice" aspect of this status, and this section will

68. See 5 TiffANY, supra note 14, $\$ 1285$ (explaining in most states actual notice or information that will put one "on inquiry in regard to [a prior] conveyance" is "sufficient, in order to deprive a person of the right to claim as against a prior unrecorded conveyance").

69. See 1 PALOMAR, supra note $13, \S 11$ (noting that the phrase "innocent" purchaser is sometimes used as the equivalent of "bona fide" purchaser).

70. It has always been the case that as an equitable matter one taking property with notice of an adverse and enforceable claim cannot claim to have the qualities of an innocent necessary to be a bona fide purchaser:

$[I] \mathrm{n}$ the period prior to the enactment of recording statutes, rules originated for the determination of priorities.... Conflicting claims not covered by statute fall into three classifications, all covered by the general law rule that the first in time is first in right, reenforced by the equity maxim that equity follows the law.... [W] hen the earlier right is equitable, the courts allow it priority in the event only that the holder of the later legal interest acquired it with notice, or did not pay value for it; if the holder of the later legal claim is a purchaser for value without notice of the earlier equitable right or interest, the equitable doctrine of bona fide purchaser prevails and it is the later claim which is protected.

4 Thomas E. Atkinson et Al., American Law of Property § 17.1, at 523-25 (A. James Casner ed., 1952).

71. See 1 PALOMAR, supra note $13, \S 11$. 
address the meaning of "notice."

Notice itself is a broad concept with a number of variations but each having the same essential effect. ${ }^{72}$ Notice may include actual knowledge of, or actual notice of, a fact. ${ }^{73}$ This means the purchaser not only had information available to him but he also knew of that information (e.g., he was told the fact, he read the fact in the records, etc.). ${ }^{74}$ Note that our protection through notice requirements is aimed at protecting a purchase, and thus what matters most is the quantum of notice available at the time the purchaser must pay consideration for the property. Many courts hold that actual notice may be express or implied. ${ }^{75}$

There is also the category of "record notice" (sometimes referred to simply as "constructive notice" even though it is only one of several types of "constructive" notice, as will be discussed in a moment) where the world is presumed to be on notice of all claims to title properly recorded and of any facts that may be included in the title, deed, and other documents filed in that record for a particular piece of property. ${ }^{76}$ And, it is the responsibility of all purchasers to check the record before purchasing property, lest they risk losing to a prior titleholder of record.

Some wonderful language on record notice exists to describe the benefits and purposes of recording in the 1881 U.S. Supreme Court opinion in Neslin v. Wells, ${ }^{77}$ which, surprisingly, turns out to be an inexplicably rarely cited opinion. Neslin is a case involving claims of priority lien status by a claimed prior mortgagee of the same land to which another mortgagee made a claim. ${ }^{78}$ Because it is so instructive and has rarely received ink in legal commentary, it is worth quoting parts of that opinion at length.

Faced with interpreting early Utah legislation that "did not require that a mortgage should be recorded in order to be valid, and did not in terms declare what should be the legal effect of recording or omitting to record it," notice that it identified as broadly applicable regardless of the type of

\footnotetext{
72. Id. $\S 12$ (defining various types of notice for recording statute purposes).

73. $I d$.

74. Id.

75. See, e.g., Faris v. Finnup, 113 P. 407, 408 (Kan. 1911) (“Actual notice may be either express or implied; that is, it may consist of knowledge actually brought personally home, or it may consist of knowledge of facts so informing that a reasonably cautious person would be led by them to the ultimate fact.").

76. $I d$.

77. 104 U.S. 428,428 (1881).

78. Id.

79. Id. at 432 .
} 
recording system in place. ${ }^{80}$ The Court reasoned that the existence of the recording system and the availability to record title there serves a purpose to which we also attach an obligation. ${ }^{81}$ Regarding real property recording systems, the Court's message seemed clear-if society builds it, purchasers must come and inspect it before purchasing:

The provisions of the law in reference to these records either have no purpose at all,- -which we have no right to assume,- - or their purpose was, that the public might have knowledge of the titles to real estate of which they are the registers. It would utterly defeat that purpose not to presume with conclusive force that the notice which it was their office to communicate had reached the party interested to receive it; for, if every man was at liberty to say he had failed to acquire the knowledge it was important for him to have, because he had not taken the trouble to search the record which the law had provided for the express purpose of giving it to him, then the ignorance which it was the public interest and policy to prevent would become universal, and the law would fail because it refused to make itself respected. ${ }^{2}$

Because "it is uniformly held that the registration of a conveyance operates as constructive notice to all subsequent purchasers of any estate, legal or equitable, in the same property," and the "policy of the registry acts" requires that one do what he can to protect himself from taking property already granted to another, such recording acts therefore create "the duty of the purchaser under such circumstances to search for prior incumbrances, the means of which search are within his power." ${ }^{, 83}$ According to the Neslin Court - regardless of whether the legislative acts of a state mandate that a purchaser inspect such available recordspractice and habit certainly have developed to the point that the real estate industry accepts these as standard practices, and, consequently, these customs have ripened into duties. ${ }^{84}$

80. See id.

81. Id. at 435 .

82. Id. at $433-34$ (emphasis added).

83. Id. at 434 (citing JOSEPH STORY, COMMENTARIES ON EQUITY JURISPRUDENCE $§ 402-03$ (Stevens \& Haynes eds., 1st ed. 1884)).

84. Id. The Court explains this process of habit leading to custom then legal expectation as follows:

It is a further inference which we are judicially bound to make, that records so carefully provided by law, and so useful, were in fact the common resort of the community whose dealings in real estate they were meant to register; that the practice of recording conveyances and incumbrances of the title to land, for the purposes of evidence and of information to those who might be affected by them, and the habit of searching the records in order to obtain that knowledge, was general and usual; that such practice and habit had become so common, that men of ordinary prudence in the management of important concerns affecting their own interests would expect to conform to it 
Non-record notice may also exist to create actual notice or to trigger inquiry notice, as it is only fair to hold a purchaser responsible for accepting title "with notice" whenever he has any reason to know that there is a valid competing, prior claimant. ${ }^{85}$ Furthermore, constructive notice is a broad term and takes on a variety of meanings within and across jurisdictions. It is mainly designed to capture those things that are available to provide actual notice-including records or other public documents that, with due diligence would have been discovered. ${ }^{86}$ For example, the existence of a fact in a record is actual notice if an individual actually reads it. But if the individual never goes to the records office, then he does not have actual notice of record facts but instead is on constructive notice (or suffers the "record notice" subset of constructive notice) of those record facts. Similarly, one may be charged with constructive notice of facts that he could have gained had he made certain inquiries after inquiry notice obligations were triggered ${ }^{87}-$ i.e. he is on notice of the facts that exist that he should have discovered with due diligence, but when he does not actually take the steps necessary to actually discover the facts and thereby "know" them, then we say that individual is on constructive rather than actual notice of the facts.

In addition to each of these categories discussed above, an extremely important and broad subcategory of notice law lies in "inquiry notice," 88 where the existence of red flags that cause one to question whether there might be an adverse claim to a particular piece of property stalls the path to becoming a bona fide purchaser. ${ }^{89}$ It is important to note that inquiry

themselves, and would act upon the expectation that others of that character would do so likewise. Id. at 435 .

85. See Palestina, supra note 13, at 1029 ("Non-record notice is recognized almost universally in recording statu[t]es throughout the United States. The reason for this is simple: it lends fairness and objective justice to the system.").

86. Miller v. Alexander, 775 P.2d 198, 202-04 (Kan. Ct. App. 1989) (defining scope of constructive notice under Kansas law).

87. Inc. Trs. of Salvation Army in Pa. v. Lawson, 143 A. 113, 114 (Pa. 1928) (describing constructive notice as including "what they could have learned by inquiry of the person in possession and of others who, they had reason to believe, knew of facts which might affect the title," including what was available in records offices).

88. 1 PALOMAR, supra note $13, \S 12$ ("Possession that is not explainable by the records is only one form of inquiry notice. If other circumstances exist that ought to put a person exercising common reason and prudence on inquiry, a purchaser will be presumed to have made that inquiry and will be charged with notice of every fact that would have resulted from it.").

89. Roberts v. Estate of Pursley, 718 A.2d 837, 843 (Pa. Super. Ct. 1998) (stating purchasers of real estate affected by actual notice and what could be discovered by inquiry upon "others, who they had reason to believe, knew of facts which might affect title" but "a purchaser will not be prejudiced by facts, which he could not have learned by inquiry"); see also Palestina, supra note 13, at 1030 ("Inquiry notice can be described as a form of 'red-flag' notice ... required to make a reasonably 
notice rules tend to apply rather uniformly in cases with competing title claims regardless of the language of recording acts, precisely because inquiry notice rules are based on equitable principles that permeate the rules for the resolution of any such disputes. ${ }^{90}$

Part V will return to inquiry notice as an underexploited opportunity for the realization of nemo dat-like outcomes. For now, this subsection will end by explaining what is meant by the term "inquiry notice" and the legal consequences that attach to this category of notice.

Inquiry notice is about taking extra steps to clear up title confusion. A purchaser may rely on the vendor's warranties and matters in the record but if there are "clues" inside or outside the records that come to one's attention, he may need to inquire further. ${ }^{91}$ As the Kansas Supreme Court explained it, for example, "[n]o purchaser of real estate is at liberty to remain intentionally ignorant of facts relating to his purchase within his reach," 92 so when one has reason to believe there may be more information to find - when the duty to inquire further is triggered - then he must reach out and start investigating. A purchaser will be charged with knowledge of whatever information could have been gleaned after making an inquiry once it has been determined that some fact triggered the duty to inquire. ${ }^{93}$ This is true even when the prior purchaser is also at fault for not having recorded title, but the subsequent purchaser had reason to be suspicious of a competing prior claim and could have

prudent investigation to either dispel or confirm his suspicion.").

90. See 5 TIFFANY, supra note $14, \S 1285$ (finding inquiry notice is "a principle well settled in equity, without reference to the recording acts").

91. See Faris v. Finnup, 113 P. 407, 408 (Kan. 1911). The Kansas Supreme Court has stated the relationship between trusting a vendor and asking further questions as follows:

No claim of express notice to the appellee is made. Actual notice is implied only when the known facts are sufficiently specific to impose the duty to investigate further and when such facts furnish a natural clue to the ultimate fact. The appellee purchased upon a warranty of full title. Consequently he was not put upon inquiry like one who accepts a quitclaim deed. He could safely rely upon his vendor's warranty unless the public records disclosed the appellant's claim or unless cogent facts outside the records, duly brought to his attention, apprised him of it.

Id.

92. Int'l Harvester Co. of Am. v. Myers, 121 P. 500, 503 (Kan. 1912); see also In re Kasparek, No. 07-13019, 2009 WL 2366400, at *7-11 (Bankr. D. Kan. 2009) (providing an extremely thorough survey of the variety of inquiry notice cases under Kansas property law), rev'd on other grounds, 426 B.R. 332 (B.A.P. 10th Cir. 2010); see also Lane v. Courange, 359 P.2d 1115, 1116-19 (Kan. 1961) (discussing inquiry notice duties and standards).

93. See Int'l Harvester Co., $121 \mathrm{P}$. at 503 ("Information which makes it the duty of a party to inquire, and shows where such an inquiry may be effectual, is notice of all the facts which might be thereby ascertained."); Jamison v. Dimock, 95 Pa. 52, 55-56 (1880) (discussing inquiry notice triggered by possession of another, holding that where "duty to make such inquiry" attaches, "having neglected to do so, [purchasers] were affected with constructive notice of such facts as would have come to their knowledge in the proper discharge of that duty"). 
learned of the prior claim on title nonetheless through proper investigation. $^{94}$

In Kuhn v. Wise, the Kansas Supreme Court in 1906 explained the basic principles regarding the raising of suspicions of a dirty deed that might trigger inquiry: "If the facts concerning the [subsequent purchaser's] knowledge were such as would prompt a prudent man to inquire concerning [grantor's] authority to sell and make conveyance, then he is chargeable with notice of the fraud, for an inquiry of the owner would have disclosed the absence of such authority." "T5 Thus, if there is good reason for a purchaser to suspect that the grantor might lack authority to sell because grantor has already sold the same property to another-even where the purchaser does not yet have a reason to know that the grantor lacks such authority - the purchaser may not proceed to bona fide purchaser status unless and until he conducts further investigation. And, if he chooses not to conduct the investigation, the purchaser will nonetheless be charged with the equivalence of actual knowledge of whatever facts he might have discovered if he had completed the mandated inquiry. As the court in Kuhn continued when faced with an argument that a subsequent purchaser "should be protected as an innocent purchaser for value without knowledge of the facts," the court explained that while "[a]ctual knowledge is not necessary," nonetheless, "knowledge of circumstances sufficient to excite the suspicions of a prudent person and put upon inquiry is, as a general proposition, equivalent to knowledge of the facts which a diligent inquiry would have disclosed." 96

The most common trigger for the duty to inquire is the possession of

94. Schechter, supra note 62, at 119 ("[T]he system favors somewhat the prior transferee: when both the prior and subsequent transferees have failed to avoid the harm, the system breaks the tie by protecting the prior transferee."); see also Bremerton Creamery \& Produce Co. v. Elliott, 50 P.2d 48 (Wash. 1935). In Bremerton, the Washington Supreme Court dealt with the two relatively guilty parties - a prior interest holder who did not record and a subsequent purchaser who did not investigate and sided with the prior interest holder:

It must be admitted that, in this case, blame rests upon each party. Defendant had at his disposal a simple and easy method by which he could have protected his rights. The filing for record in the office of the auditor of Kitsap county of a certified copy of the decree of distribution would have placed any purchaser of the land in that county upon notice of his claim. On the other hand, plaintiff purchased the land and paid the consideration therefor without a careful investigation of the extent and nature of its grantor's title. In this connection, it is proper to consider that defendant's lien is something entirely extraneous to the chain of title. It rests upon an agreement ... Id. at 54 .

95. Kuhn v. Wise, 135 P. 571, 573 (Kan. 1913).

96. Id. 
a property by someone other than the grantor. ${ }^{97}$ Inquiry can also be triggered from suspicious words or statements in recorded documents that cause one to question possible encumbrances on title (or use).$^{98}$ And, strikingly, in jurisdictions like Kansas, for example, quitclaim deeds are even possible triggers for inquiry by a purchaser on a presumption that, if a grantor proceeds by quitclaim deed, he is unwilling to warrant against defects in title and therefore a red flag may exist regarding the grantor's authority to convey or lack thereof ${ }^{99}$-rather inexplicably so given the variety of legitimate and efficient reasons for transferring property by the quitclaim method.

But, inquiry can be triggered in a whole variety of other ways too, even when the conveyance includes warranties or covenants of title like one gets with the transfer of a general warranty deed. Even there, facts might nonetheless be present and surrounding the circumstances or parties to the transaction that cause the prudently curious or cautious buyer to ask additional questions as part of his due diligence. When that is the case, the law does more than just suggest that such inquiry be made: it demands it. It is that state of the law regarding inquiry notice that is further explored in Part V where extensions to it are proposed.

Once the inquiry duty is triggered, the purchaser is required to make "such investigation as may reasonably be demanded of a person of ordinary diligence and understanding," and if, after doing so, he "fails to ascertain the existence of the adverse claim, any inference of notice is rebutted" and the law acts as if there is no notice of any adverse claim. ${ }^{100}$ Inquiry notice determinations by a court are highly fact-specific. ${ }^{101}$ And,

97. Int'l Harvester Co., $121 \mathrm{P}$. at 502-05 (cataloguing cases holding that possession by another is a trigger for inquiry notice and where those that do not investigate such open and notorious possession cannot be bona fide purchasers).

98. 5 TIFFANY, supra note $14, \S 1262$ ("[T] he record is notice not only of the instrument and of the facts stated therein, but also of any other matters as to which the necessity of an inquiry is suggested by statements in the instrument.").

99. Despite the fact that quitclaim deeds have many efficient uses (including sometimes to actually resolve title disputes) and many jurisdictions will not automatically eliminate bona fide purchaser status for the recipient of a quitclaim deed, some jurisdictions recognize that they may raise suspicions regarding title. See, e.g., Pope v. Nichols, 59 P. 257, 259 (Kan. 1899) (finding quitclaim deeds raise special cautions that almost immediately require grantee to conduct further inquiry); Samuel Ashe Fitch, Vendor and Purchaser-Purchaser Under a Quitclaim Deed, 6 TEX. L. REV. 518, 518-19 (1928) (stating that quitclaim deed purchasers in Texas "may not raise the plea of a bona fide purchase for value and without notice as to prior unrecorded conveyances" because "the grantee, by the taking of a deed without warranties, has admitted the shortcomings of his vendor's title; that he is therefore placed on notice as to its defects and should not be later heard to complain of the (if subjected to) assertion of an outstanding paramount title").

100. 5 TIFFANY, supra note 14 , $§ 1285$; see also 3 PALOMAR, supra note 13, $\S 673$ (describing diligence requirement in inquiry notice).

101. 5 TIFFANY, supra note $14, \S 1285$ ("Each case must, to a very considerable degree, depend 
one need not make inquiry if such an effort would be futile, ${ }^{102}$ although it is a bit risky to make that determination before an investigation has even begun. ${ }^{103}$

To sum up (and with an analogy to some (in)famous words of former Secretary of Defense Donald Rumsfeld), ${ }^{104}$ consider the following characterizations of notice. Bona fide purchasers will be protected against the unknown, or perhaps more precisely, they will be protected from the things that they do not know that they do not know. ${ }^{105}$

There are the things we know that we know. When there are "known known" adverse title claimants, notice of these parties strips a party from eligibility for holding bona fide purchaser status. ${ }^{106}$ There are those things that might be categorized as "known unknowns"- one knows something is potentially wrong and needs to search and investigate, i.e. conduct an inquiry, and dismiss the suspicions before he can proceed to warrant status as a bona fide purchaser. And then there are the worst of all conditions-where there are things that a purchaser does not (and with available information cannot) know that he does not know, or the "unknown unknowns." This last category will most often be the situation where the prior purchaser has done nothing - by recording or otherwise - to make the public aware of the threat that his claim to title priority has for the acquisition of the same property by others. Because of the market disruptive effects of these hidden facts-the "unknown

upon its own peculiar circumstances, and it is impossible to frame any absolute rule ....").

102. Lower's Appeal, 1 Walk. 404, 412 (Pa. 1872) (finding the purchaser should not be prejudiced for not making inquiry if such inquiry would be fruitless or nonbeneficial); see also 5 TIFFANY, supra note $14, \S 1285$.

103. Therefore, the risk-averse purchaser may want to expend some resources doing at the very least a preliminary investigation from which there is a legitimate reason to believe further effort would be futile.

104. In discussing the situation in Iraq and the possible existence of weapons of mass destruction, Donald Rumsfeld famously explained the differences between "known knowns," "known unknowns," and "unknown unknowns":

Reports that say that something hasn't happened are always interesting to me, because as we know, there are known knowns; there are things we know we know. We also know there are known unknowns; that is to say we know there are some things we do not know. But there are also unknown unknowns - the ones we don't know we don't know. And if one looks throughout the history of our country and other free countries, it is the latter category that tend to be the difficult ones.

Donald H. Rumsfeld, United States Sec'y of Def., DoD News Briefing-Secretary Rumsfeld and General Myers (Feb. 12, 2002) [hereinafter Rumsfeld Transcript], http://archive.defense.gov/Transcripts/Transcript.aspx?TranscriptID=2636.

105. Metzger v. Mueller, 238 P.2d 802, 803 (Okla. 1951) ("The rule is well established that in the absence of actual or constructive notice of a previous conveyance, or of matters which would put a purchaser on inquiry, a bona fide purchaser for value will take a good title to the property.").

106. See Hutchinson v. Harttmann, 15 Kan. 133, 141 (Kan. 1875) (defining bona fide purchaser). 
unknowns"- the prior titleholder, who is the least cost avoider of that state of public ignorance, ${ }^{107}$ will not be protected in his claim against a bona fide purchaser without notice. ${ }^{108}$

Recording systems themselves are really just notice systems. ${ }^{109}$ By understanding when and how notice of adverse claims makes it into the information flow of the market and the legal consequences associated with the availability of adverse title facts, we can begin to understand the limited nature of the nemo dat exceptions associated with recording and the purposes for accepting those exceptions. Although the recording laws are often explained in the ways discussed in this preceding Part, it is rare to see a discussion dissecting their specific relationship with, and effect on the strength and utility of, the nemo dat principle as Part IV will venture next to do. The next Part explores in more detail the purposes behind tolerance for deviations from the nemo dat norm, and it begins to advocate for greater attention to ways that we can improve the system to minimize the occurrence and application of such deviations.

\section{FURTHER ON IDENTIFYING THE CONFLICTS BETWEEN RECORDING PRIORITIES, NEMO DAT PREFERENCES, AND PROPERTY LAW PRAGMATISM}

The risk that a grantor will sell dirty deeds, where the same piece of property is conveyed more than one time and to more than one person, is not just a law school hypothetical; it is a real and recurring threat. ${ }^{110} \mathrm{Bad}$ actors exist and will try to exploit holes in the legal system or time gaps

107. See infra Part IV.B (describing opportunities and obligations for prior and subsequent purchasers).

108. Pomeroy, supra note 40, at 141 (explaining recording acts and title insurance are designed so that "bona fide purchasers of real property are protected against unknown third parties later claiming superior title or rights").

109. Douglas C. Harris \& May Au, Title Registration and the Abolition of Notice in British Columbia, 47 U.B.C. L. REV. 535, 540 (2014) (identifying the recording or registry offices themselves as principally “"notice' systems”).

110. See Scheid, supra note 13, at 102 ("Because a transfer of an interest in real property can be accomplished discreetly, the possibility of a grantor conveying an interest to one grantee and then conveying the same (or a lesser conflicting) interest to a subsequent grantee is a real one."); Cory Torgesen, Comment, The Illinois Conveyances Act: A 200-Year-Old Labyrinth Whose Changing Walls Continue to Provide Inadequate Protection for Subsequent Purchasers, 37 S. ILL. U. L.J. 695, 701 (2013) ("[T]ransactions involving bona fide subsequent purchasers are not uncommon. Similar situations are widespread ....”); see also Kroetch v. Hinnenkamp, 18 P.2d 491, 491-92 (Wash. 1933) (protecting bona fide subsequent purchaser in situation where a couple sold property once by warranty deed in 1910, but original purchaser did not record the deed until 1931, and in the interim, the couple sold the same property in 1929 to another by quitclaim deed and the deed was promptly recorded). 
in recording to perpetrate these types of dirty deeds. ${ }^{111}$ It is this reality that has motivated policymakers to establish the systems of priority between purchasers that must be used to resolve contests between the grantees that may be subject to this type of grantor behavior. ${ }^{112}$ Even beyond those systems already in place, it is this reality that also calls for more experimentation with innovative measures like TINTS to protect against such bad behaviors, as is discussed further in Part V of this Article.

Professor Audrey McFarlane makes several interesting observations on bad actors and the dirty deed phenomenon. ${ }^{113}$ Although her critique ends with a call for limits on the transactional and market-centered focus in setting property rules ${ }^{114}$ (something beyond what this Article would endorse), her analysis of the behaviors involved to which we should seek a remedy is instructive. McFarlane describes the reality of property's acceptance of certain "scurrilous behavior" as follows:

In the first-year Property course, law professors have the unenviable task of introducing students to a difficult concept to grasp: the grantor $O$ has the power to convey property to a first person, let's say $A$, and then for whatever reason-fraud, deceit, caprice, or good-faith mistake - has the ability to re-convey the property to a second person, $B$. In other words, $O$ has the power to convey property twice.

111. Cf. Black, supra note 5, at 525 (discussing principally con artist sales rather than multiple conveyances of a property one actually at one point owned, but nonetheless illustrating that "[i]n discussing property ... we sometimes confront the situation where the seller does not actually own the property that he is trying to sell"). Singer also poignantly explains that "[t]he problem of Holmes's 'bad man' who wants to know what he can [get] away with turns out to be an especially tricky dilemma for property law." Joseph William Singer, The Rule of Reason in Property Law, 46 U.C. DAVIS L. REV. 1369, 1432 (2013).

112. See Reppy, supra note 54, at 198 (explaining outcomes in race-notice jurisdiction when grantor sells same property to two different people); Lesley Rowe, Note, The Decline and Fall of Constructive Notice, 65 MERCER L. REV. 1203, 1207 (2013) ("Under Georgia's race-notice scheme ... if two deeds from the same seller convey the same property, the recorded deed with a later date takes priority over the earlier unrecorded deed.") (footnote omitted); Torgesen, supra note 110, at 696-97 (discussing outcomes under each type of recording statute and using an example where grantor sells the same house to one person in the morning and another in the afternoon, which illustrates the pivotal role of notice when it is determinative).

113. See McFarlane, supra note 3, at 882-86.

114. Id. at 885-86 (explaining if we really want to stop fraud-a moral conclusion-then we will need to rein in "today's instrumental rationale for property" and limit power of "the transactional nature of property" law).

115. Id. at 883 . The seeming necessity to accept such fraud is particularly troubling because the victims of it are often poor, minorities, or otherwise disadvantaged. See id. at 885 (arguing the lines we draw to find that some "force, fraud, and coercion" is "acceptable" are "drawn in a way that fails to acknowledge that force and fraud will be concentrated towards one end of the spectrum, or to say it another way, concentrated racially, by class and geography"). 
The concept of a grantor selling property to $B$ after he has already sold it once to $A$ is difficult to wrap your arms around because it runs counter to our gut and our appreciation for the difference between right and wrong.

This Part is intended to explain some of the policy choices that have been made in establishing title priorities knowing that those choices affect a deviation away from the nemo dat paradigm. To understand how these rules have developed, and as a foundation for understanding later why we accept exceptions to the nemo dat principle, it will be helpful to examine a bit further, in the first section of this Part, the utility and purposes of real property recording systems.

\section{A. Recording Generally, Including Supporting a Stable, Predictable, Confident, and Transparent System of Property Transfers Toward Achieving High Levels of Certainty and Lower Levels of Risk}

Property transactions are dependent on a well-functioning system for the transfer and recordation of title. ${ }^{116}$ The fact is that recording systems are information systems; and, information is the currency through which efficient property transactions, including conveyancing and the transfer of title, operate. As the U.S. Supreme Court explained in the 1868 opinion in Patterson v. De La Ronde:

[T] he object of all registry laws is to impart information to parties dealing with property respecting its transfers and incumbrances, and thus to protect them from prior secret conveyances and liens. It is to the registry, therefore, that purchasers, or others desirous of ascertaining the condition of the property, must look, and if not otherwise informed, they can rely upon the knowledge there obtained. ${ }^{117}$

A formalized system of property recordation becomes a fundamental institutional support for the market. ${ }^{118}$ The market has demanded and

116. See generally Kochan, supra note 2, at 270-72; see also Heather K. Way, Informal Homeownership in the United States and the Law, 29 ST. LOUIS U. PUB. L. REV. 113, 120 (2009) ("Title is a legal construct that defines the ownership interest someone holds in an asset. In the context of homeownership, title allows one to determine who owns what property interests in a home, and then determine who has legal authority to use, enjoy, encumber, and transfer the property.") (footnote omitted).

117. 75 U.S. 292, 300 (1868).

118. See, e.g., Hernando de Soto, The Mystery of Capital: Why Capitalism Triumphs IN THE WEST AND FAILS EVERYWHERE ElSE 46-67 (2000) (explaining importance of "formal property system[s]" to capitalism in the West); HeRnANDo DE SOTO, THE OTHER PATH: ThE INVISIBLE REVOLUTION IN THE THIRD WORLD 158-63 (June Abbott trans., 1989) [hereinafter DE 
preferred the higher level of certain information and lower levels of risk that recording systems offer and has demonstrated a willingness to accept the limitations these systems place on the operation of the nemo dat principle and its corresponding attributes. ${ }^{119}$ Professor Joseph Singer explains that "[t]his system [of recording] helps clarify the state of the title and provides buyers with assurances that the person purporting to sell them land actually owns it and that the land is not subject to any competing claims or encumbrances," because buyers must always be worried that claims may exist "that might conflict with their ability to obtain title or use the property as they wish." 120

The recording system fits within a broader array of mechanisms by which owners of property seek title assurance. ${ }^{121}$ As Professor Heather Way explains, title assurance mechanisms-including recording systems - are designed to work toward providing efficient mechanisms for establishing clear title in a manner that minimizes disputes and allows property to flow freely and smoothly in commerce:

One of the touchstones of real property security in the United States has been the creation of extensive title recording systems at the state level which create a written record of the chain of title. These public recording systems, along with quiet title actions, laws that extinguish ancient claims, and other property laws, favor the creation of clear and reliable property interests, while disfavoring ambiguous or contested ownership interests. Title insurance further facilitates the creation of secure title interests by insuring a property owner from third party claims to the property.

Every state in the United States has established some form of recording or registration infrastructure for real property. ${ }^{123}$ Recording is a local enterprise, where states develop rules for recording and local offices typically handle the actual recordation and indexing and serve as the critical repositories of information on title and the transfers of it for particular properties within a jurisdiction. ${ }^{124}$ Records and registration

\footnotetext{
SOTO, OTHER PATH) (explaining costs of not having "secure, reliable property rights").

119. See, e.g., McFarlane, supra note 3, at 885-86.

120. SINGER, supra note $13, \S 11.4 .5 .1$, at 538 .

121. See Way, supra note 116 , at 121.

122. Id. (footnotes omitted); see also BENITO ARRUÑadA, Institutional Foundations of IMPERSONAL EXCHANGE: THEORY AND POLICY OF CONTRACTUAL REgISTRIES 2-4 (2012) (describing the market utility gained from publicizing property rights through registration systems).

123. Pomeroy, supra note 40, at 141; Korngold, Resolving, supra note 18, at 1564 ("While the recording acts differ among the states in some respects, they share many common models, attributes, and goals.").

124. Tanya Marsh, Foreclosures and the Failure of the American Land Title Recording System,
} 
offices are places that provide information individuals need to determine the state of title and the contents of deeds, in order to determine who owns what and with what conditions, ${ }^{125}$ and particularly to identify whether a property that one seeks to acquire or engage with in some other way is encumbered by other claimants. ${ }^{126}$

The purpose of recording systems has always been the same: to provide a network of reliable, accessible, public, verifiable ownership information in a certain and identifiable place for inspection so that all parties interested in learning the title ownership status and other deedrelated details of property could find such information and feel confident in assessing their current or future relationship with that property based on the information they can find in the records offices. ${ }^{127}$

There is no reason, however, to limit ourselves to providing informational inputs into this network only through traditional land records. As we examine recording and its utility in this Part, one should start to see how other innovations designed to achieve the same goals as recording might also be adopted to supplement the network of information beyond what is provided in the recording system to even better achieve access to verifiable and perhaps even more complete titlebased information. The reader should keep in mind the lessons the remainder of this Part will explain about recording when evaluating the proposal in Part V and in developing the reader's own innovative ideas

111 Colum. L. REV. Sidebar 19, 20-24 (2011), http://www.columbialawreview.org/wpcontent/uploads/2011/03/19_Marsh.pdf (discussing the mechanics of recording and indexing and the problems and difficulties associated with the process).

125. Way, supra note 116, at 122 ("Property laws that produce clear title interests make it easier to move property in the market in several ways. They allow the market to determine who owns what interests in an asset and thus facilitate free trade of the asset on the open market.") (footnote omitted); see also Pomeroy, supra note 40, at 147 (discussing predominance of notice-type recording statutes and their purpose to "protect subsequent transferees from all manner of secret transfers").

126. Korngold, Resolving, supra note 18, at 1564 ("The recording acts and related rules were developed to establish a public system of land records that would protect ownership interests in land and accurately reflect that information for anyone to examine.").

127. See Raymond H. Brescia, Leverage: State Enforcement Actions in the Wake of the RoboSign Scandal, 64 ME. L. REV. 17, 21-22 (2011) (describing the useful functions of recording mechanisms). De Soto also explains the broad utility of recording systems:

$[\mathrm{P}]$ roperty has got to be in a place where everything is standardised, it's got to be accountable, it's got to be functional, you've got to make it liquid, it's got a network, it's got to protect transactions, and it's got to be recorded.... [W] hat property does, is effectively it creates one of the world's most important information systems that have ever existed. You really know who owns what, and who has whose hand in whose pocket, and who has a claim and not, thanks to records.

Hernando de Soto, Remarks at International Bar Association's 2008 Annual Conference (Oct. 12, 2008), in Law Connects, INT'L BAR NEws, Dec. 2008, 14, 18 [hereinafter de Soto, Law Connects]. 
for possible reforms.

The recording acts have generated market confidence in the transfer of property in a very real way because buyers and sellers have greater predictability in the enforcement of their conveyances. ${ }^{128}$ Before recording systems were the norm and under the first-to-file priority systems where record offices were less common and mattered less, there was not a place to make a reliable search toward a confident conclusion regarding the existence or non-existence of competing title claimants or other adverse property interests. With recording requirements and norms, that gap is filled. Property title gains indicia of quality, value, and utility when documented through recording in a manner that could not happen effectively otherwise. ${ }^{129}$

Prospective purchasers, in particular, demand a verifiable repository of title information to guide their property acquisition decisions, along with demanding other backstop security devices (such as title insurance, for example) for when that system is incomplete or otherwise unsatisfactory in its level of protection. ${ }^{130}$ The records offices strive to supply that product (although there are, of course, imperfections and unreliable elements to these offices - as with any bureaucratic system and especially ones that are still largely dependent on old paper-based records systems - those complications are beyond the scope of this Article). Although this Article is concerned principally with clear and identifiable title between two successive purchasers of property, there is no doubt that many others besides those competing for title also demand or benefit from the ability to identify titleholders with clarity, including, for example, creditors. ${ }^{131}$

128. Gerald Korngold, Legal and Policy Choices in the Aftermath of the Subprime and Mortgage Financing Crisis, 60 S.C. L. REv. 727, 739-40 (2009) [hereinafter Korngold, Legal and Policy Choices] (examining the development of recording acts in the United States that have "allowed buyers of interests in real property to trade in confidence and encouraged markets for sales and financing").

129. Hernando de Soto, Why Capitalism Works in the West but Not Elsewhere, INT'L HERALD TRIB. (Jan. 5, 2001), http://www.cato.org/publications/commentary/why-capitalism-works-west-notelsewhere ("To be useful in an expanded market, capital must first be represented in a property document where it can then be assigned a status that allows it to produce additional value. What most people possess outside the West is not 'paperized' in such a way as to produce capital.").

130. See id.

131. Way, supra note 116, at 122. Professor Way explains:

Clear title also facilitates outside investments in property by allowing creditors to have faith in the property interest they are securing. When title interests are insecure or unclear, creditors will either refuse to invest in the property or, alternatively, devalue the asset to take into account the higher risk of the investment or the transactional costs of making the title interests more secure.

Id. See also Levinz v. Will, 1 Dall. 430, 433 (Pa. 1789) (“Property is the foundation of credit."); DE 
Property recording systems provide valuable reference material for all sorts of individuals and entities interested in learning about the title, deeds, and other characteristics associated with a piece of property. ${ }^{132}$ The repositories of records provide a level of transparency that allows markets in property to operate, including the capability to discover who holds title to what under what deed terms and with what conditions, or to identify what other parties are involved with the property in one way or another to complicate the matter legally. ${ }^{133}$ Instability in property markets arises when such features of a parcel of property are not exposed, cannot be examined, and have not been committed to the public memory system for use in evaluating transactions related to the property. ${ }^{134}$ Markets in property can operate efficiently but only with optimal levels of information and systems for the verifiability of information, including records offices and neutral courts. ${ }^{135}$

Recording systems connect participants in the marketplace for property, providing accessible public knowledge databases. ${ }^{136}$ Because there are means of verifying title, market participants can have a higher degree of confidence-i.e. a higher degree of certainty - in what they and other parties with whom they will interact own and have authority to transfer. Importantly, the market participants and the enforcement machine-principally courts-can all use the system to make

SOTO, OTHER PATH, supra note 118, at 162 (explaining the absence of reliable property systems "inhibit the use of property as collateral, one of the various benefits traditionally conferred on property owners"); id. ("This is because a lender must make the same costly investments as a purchaser in order to make sure that the property is under the borrower's control and that, in the event of a default, the property can be obtained with the same rights as those enjoyed by the present owner.").

132. Marsh, supra note 124, at 20 (describing the goals of the recording system, particularly the provision of notice to the world, including to prospective buyers).

133. Korngold, Resolving, supra note 18, at 1564 ("This system has served to create an active and safe American real estate market by providing security of titles and realty interests, enabling the efficient use of land as collateral for loans, and allowing prospective buyers to locate owners and bargain with them over potential deals."); see also de Soto, Law Connects, supra note 127, at 18 (explaining we do not know who owns what without clear records).

134. Hernando de Soto, The Destruction of Economic Facts, BLOOMBERG BUSINESSWEEK (Apr. 28, 2011), http://www.businessweek.com/magazine/content/11_19/b4227060634112.htm (describing recording systems as "public memory systems").

135. Korngold, Resolving, supra note 18, at 1562 ("The land records system and related rules should be designed to create a high-functioning, efficient market."); Thomas J. Miceli et al., The Dynamic Effects of Land Title Systems, 47 J. URBAN ECON. 370, 370 (2000) ("[T]he more clearly defined the property rights, the greater the land market efficiency."); see also Mark Ellis, Legal Profession Must Shape Our Post-Crisis Future, INT'L BAR NEWS, Oct. 2010, at 7 (crediting de Soto for articulating why "clarity of legal title has been the foundation of all modern economic growth").

136. de Soto, Law Connects, supra note 127, at 18 (explaining when the recording system is non-existent or failing, then '[w] hat you've lost is your capacity to connect, because you've lost the track that property gives you"). 
determinations on relative priorities of title and other deed rights. Judicial outcomes are predictable, and parties can transact against reliable assessments of enforceability risks, based on those predictions.

Security, stability, and verifiability of title become operational with title recording systems. ${ }^{137}$ Confidence in making investments and improvements in property follows. ${ }^{138}$ The more secure title is, the more that an owner can demand for the property, because a buyer is willing to pay for that strong asset associated with the property. Real value in "ownership" of property is determined by the degree to which these additional asset qualities - confidence, certainty, stability, predictability, and enforceability of title-obtain. ${ }^{139}$

All in all, certainty of ownership is vital in facilitating private market-based transactions for property, and records in recording offices provide that benefit in a way that unrecorded title documents cannot. ${ }^{140}$ Willingness to invest in property or to extend credit on good terms based on property as a security device is directly proportional with the level of certainty in title, the concomitant level of risk, and the confidence the investor has in being able to identify the legitimacy of the enforceable title. ${ }^{141}$ Investment risk is lower when title is more certain. ${ }^{142}$

Similarly, owners will not improve property that they are not entirely confident they own. If you are always worried about a knock on the door from an adverse claimant, you will be less likely to labor and invest to improve your property because you fear losing the fruits of that effort. If the recording system is structured in a way where such an owner can attain a higher level of confidence, society is better off because the

137. McFarlane, supra note 3, at 863 ("[T]here is little debate that the underlying purpose and goal of property law is to promote and support stability."); David E. Woolley \& Lisa D. Herzog, MERS: The Unreported Effects of Lost Chain of Title on Real Property Owners, 8 HASTINGS BuS. L.J. 365, 368 (2012) ("[T]he stability of the land title is paramount in preserving land ownership and maintaining civil harmony ....").

138. Abraham Bell \& Gideon Parchomovsky, A Theory of Property, 90 CORNELL L. REv. 531, 552-59 (2005) (discussing generally the importance of stability in property ownership and policing mechanisms for the same).

139. Id. at 552 (" [A] property system with stable rights increases the value of assets to users (now owners) and decreases the costs of obtaining and defending those assets.").

140. Schechter, supra note 62, at 109 (acknowledging that "a number of commentators seem to agree that the fundamental goal of any recording system is to promote the certainty of land titles" and agreeing that "certainty is an important goal of the system, but it is not the only goal").

141. de Soto, Law Connects, supra note 127, at 16 ("[G]lobally . . the problem is that nobody's going to invest unless they know who owns it, or that they own it. Nobody's going to remove the rocks; nobody's going to put in the irrigation systems or the roads, until they feel they own it.").

142. Id. at 14 ("[T]hrough law and legal documents ... you're able to identify facts [and] able to identify risks.”). 
property will be put to higher and better uses and move in commerce. ${ }^{143}$

So, the existence of neutral, third-party means of verifiability to which market participants can turn to identify who owns what (including authoritative repositories of title information through recording and a judicial system that will enforce rights according to understood terms) has market-lubricating effects that produce the market-induced values that we attach to property. ${ }^{144}$ In the words of Hernando de Soto, being serious about recording "allows the whole economy to move." 145

\section{B. The Role for Responsibility: Opportunities and Obligations of Prior and Subsequent Purchasers}

Whether one is talking about the recording laws in the United States or registry laws elsewhere, these laws create systems that reflect the necessity to make a choice between two often seemingly innocent parties who each purchased the same property from the same grantor, usually leaning toward the protections created for later-in-time bona fide purchasers against those holding prior-conveyed title. ${ }^{146}$ Choices must be made between multiple claimants to property and inevitably someone will lose and his rights will be subordinated in the zero-sum decision to award property to the other. ${ }^{147}$ We cannot have a stable system if both parties have equal claim to the property. ${ }^{148}$ McFarlane calls this choice a "market-smoothing mechanism" and explains that "in the case of a dispute, recording acts are tailored to protect buyers and sellers, but not owners. Thus fraud, despite our protestations to the contrary, is part of

143. Way, supra note 116, at 121 (“American property laws supporting clear title and more formal landholdings have historically promoted two key values: security and alienability. Security in ownership - the principle that an owner's property rights cannot be taken away, except by the government with just compensation - is a fundamental attribute of American property ownership."); cf. McFarlane, supra note 3, at 882 (explaining the recording system promotes alienability while expressing concern over that fact).

144. Id. at 885 ("Recording acts reflect an unquestioned principle that a market-based property system must contain a market-smoothing mechanism.").

145. de Soto, Law Connects, supra note 127, at 16 ("[P]roperty paper ... is what allows the whole economy to move.").

146. See, e.g., Harris \& Au, supra note 109, at 536 (explaining that registry statutes and rules must "find a balance between defending existing interests in land and facilitating transfers," and that they necessarily "reflect a policy choice in systems of land law to provide greater certainty for purchasers of interests in land at the expense of those holding existing interests").

147. McFarlane, supra note 3, at 885 ("[R]ecording acts facilitate the property markets, but also can and do undercut property ownership. Recording acts promote commerce, but sometimes at the expense of the individual.").

148. Id. at $863 \mathrm{n} .34$ (citing sources regarding the principle of setting property rules where they best promote stability). 
property."149 We know that there will be losers and that bad actors may get away with their dirty deeds, although we try to find ways to both punish and deter the bad actors.

Whereas first-in-time and common law priority conform with a stricter adherence to the nemo dat maxim, ${ }^{150}$ modern recording laws that adopt notice or race-notice priority rules favor the subsequent "innocent" purchaser and represent a relaxation of the nemo dat rules. ${ }^{151}$ The primary justification becomes based on the concept of relative or sometimes-termed comparative innocence. ${ }^{152}$

Recording statutes try to balance protecting existing owners by giving those parties methods for providing constructive notice through recording and protecting careful bona fide purchasers who search in advance of purchasing and find no competing, adverse prior interests. ${ }^{153}$ Proponents of notice and race-notice recording laws contend that while the first purchaser may in fact be innocent at the time of the transaction, the law places upon that party certain affirmative duties if he is to maintain that innocence. ${ }^{154} \mathrm{He}$ has a responsibility to himself and also to the public to make it known that he has laid claim to the property. ${ }^{155}$ The failure to warn other parties of his claim by making a public record of it becomes a type of irresponsible (and some even say fraudulent) act in and of itself that unnecessarily imposes uncertainty, risk, and high information-gathering costs on others. ${ }^{156}$

\footnotetext{
149. Id. at 884 .

150. See SINGER, supra note $13, \S 11.4 .5 .2$, at 541-44.

151. See Reppy, supra note 54, at 197-98.

152. See Cunningham v. Norwegian Lutheran Church of Am., 184 P.2d 834, 840 (Wash. 1947).

153. McFarlane, supra note 3, at 883.

154. In Poplin v. Mundell, the Kansas Supreme Court was confronted with a case involving identifying the duty of the first purchaser to record where the clerk was the sole party in error in recording and making deed publicly available so that subsequent purchaser was unable to discover competing claim. 27 Kan. 138, 139-41 (Kan. 1882). Despite recognizing some exceptions and difficult choices in those circumstances, the general and usually applicable rule, absent special circumstances, is as follows:

$[I] \mathrm{t}$ is held that the obligation rests on the party holding the conveyance to give the notice required by the statute. It is said that he controls the conveyance, and can put it on record or not, at his pleasure; that if from any cause he falls short of giving legal notice, the consequences must fall on himself; that it is his own business, and that he must suffer the consequences of its being imperfectly performed; that it is the duty of the party filing the instrument, as between him and subsequent bona fide purchaser, to see that all of the prerequisites of a valid and complete registration are complied with.

Id. at 157 .

155. Id.

156. Schechter, supra note 62, at 123 (explaining why all prior transferees are subject to the same burden regardless of whether their non-recording was negligent or fraudulent because in both cases they are the cause of unnecessary cost to the system).
} 
With the great privilege of property ownership comes a low cost responsibility to record one's interest. ${ }^{157}$ As the U.S. Supreme Court explained, resolving these conflicts "in equity requires that the loss, which in consequence thereof must fall on one of the two, shall be borne by him by whose fault it was occasioned." 158 And, the "fault" is usually identified as the non-publicizing of the prior purchaser's claim to title. ${ }^{159}$ One leading treatise explains that the law is forced to recognize that, between two claimants, one must lose, and important policies support and outweigh what at first appears to be the "trampling" of the rights of prior purchasers of property:

This involuntary loss of rights results from the overwhelming public policy of encouraging trade by guarding buyers regardless of what individual legal rights may be trampled in the dust. Since our civilization cannot live without trade and since trade cannot exist without buyers and since no buyer will pay adequate consideration unless he is certain of receiving good title when he parts with his consideration, such civilization must provide a means of guaranteeing that he will receive an indefeasible title. The "bona fide purchaser" rule is the result. If one is a "bona fide purchaser" he takes good title. The sole question is, is he a bona fide purchaser for value without notice? ${ }^{160}$

If the first purchaser fails to protect himself by providing record notice to the world, he is negligent at best ${ }^{161}$ and fraudulent or deceptive at worst, ${ }^{162}$ and it is seen as not unjust that the prior interest holder will

157. See ANDERSON \& BOGART, supra note 17, at 541 (explaining the "minimal step" of recording that the law encourages in order to avoid losing property to a subsequent purchaser).

158. Neslin v. Wells, 104 U.S. 428, 437 (1881).

159. See id.

160. 8 GEORGE W. THOMPSON \& JOHN S. GRIMES, COMMENTARIES ON THE MODERN LAW OF REAL PROPERTY § 4312, at 363 (repl. 1963).

161. 1 PALOMAR, supra note $13, \S 17$ ("Grantees who fail to give notice by recording their conveyances negligently leave the way open for their grantors to convey to others who have no notice of a prior transfer.").

162. The U.S. Supreme Court has explained why it is somewhat like a "fraud" if the first purchaser does not give notice by recording when that option to protect himself is available:

The rule to be applied here is merely an extension of that declared by Lord Chancellor Macclesfield in Savage v. Foster (9 Mod. 35, 37),- -When anything in order to a purchase is publicly transacted, and a third person knowing thereof, and of his own right to the lands intended to be purchased, and doth not give the purchaser notice of such right, he shall never afterwards be admitted to set up such right to avoid the purchase; for it was an apparent fraud in him not to give notice of his title to the intended purchaser...."

Neslin, 104 U.S. at 438-39. Similarly, the Pennsylvania Supreme Court, in examining a very early recording statute, discussed how we encourage recording to "prevent honest purchasors, or mortgagees, of real estates, from being deceived by prior secret conveyances, or 
lose in a battle with a subsequent purchaser without notice (especially if the lack of notice is due to the failure to record on the part of the first grantee). ${ }^{163}$ As Professor Dan Schechter explains, it is a matter of setting burdens to minimize costs:

$[\mathrm{O}]$ nce the challenger - the subsequent transferee - crosses the "harm threshold," the recording system then determines whether the parties have used reasonable means to avoid the harm and have thus crossed the "cost avoidance threshold." If the subsequent transferee has failed to take advantage of a reasonable opportunity to avoid the harm, then the inquiry ends, even if the prior unrecorded transferee caused the problem in the first place [by not recording].

Similarly stated, the displacement of prior purchasers in favor of subsequent bona fide purchasers without notice might be justified as placing the burden on the "cheapest cost-avoider." 165 Recording itself is relatively low cost, and it should be done by the person who knows of their own claim rather than requiring some lengthy and impossible investigation by every purchaser to ascertain from the hinterlands all possible adverse claims, all of which lie outside their personal knowledge (unlike the first actual purchaser who knows of his own purchase). ${ }^{166}$

Unrecorded (and undiscoverable) title claims are problematic. Technically, the absence of evidence of a prior claim is not evidence of the absence of a prior claim, because there may be a claim, just an unrecorded one. ${ }^{167}$ But the absence of evidence in the recording context

\footnotetext{
incumberances ....” Levinz v. Will, 1 Dall. 430, 435 (Pa. 1789).

163. Consider the following from the U.S. Supreme Court opinion in Neslin:

Who would be willing, or could afford, to purchase under such circumstances, if after every reasonable effort to inform himself of possible incumbrances a mortgagee holding an incumbrance of prior date, and whose failure to give such public notice of the fact as the law had furnished the means of giving had betrayed him into the purchase, should nevertheless be permitted to supersede his title, by asserting a parmount [sic] lien? Certainly there would be no injustice, and we think no violation of legal principle, in such circumstances, in preferring over his claim that of the innocent party, who otherwise would suffer loss, occasioned by a fraud which his laches alone hed [sic] made effective.

Neslin, 104 U.S. at 436 (emphasis added).

164. Schechter, supra note 62, at 118.

165. 1 PALOMAR, supra note $13, \S 17$.

166. Id.

167. Secretary Donald Rumsfeld borrowed Carl Sagan's famous phrasing regarding the existence of extraterrestrial life, that "the absence of evidence is not evidence of absence," in his "known unknowns" news conference. See Rumsfeld Transcript, supra note 104. See also CARL Sagan, The Demon Haunted World 213 (1996); Roger Cohen, Rumsfeld Is Correct-the Truth Will Get Out, N.Y. Times (June 7, 2006), http://www.nytimes.com/iht/2006/06/07/world/IHT07globalist.html.
} 
might as well be "evidence of absence" for purposes of the recording laws, unless something else sparks a suspicion that triggers an inquiry for a purchaser to find such an adverse claim. ${ }^{168}$ When a title claim does not appear in the records, it is the equivalent under the law of the prior claim not existing at all, as the U.S. Supreme Court reasoned in Neslin:

[T]o withhold from the record conveyances or incumbrances in their own favor is a waiver of their right, and equivalent to a representation that they do not exist, in favor of innocent subsequent purchasers, who otherwise would be wrongfully affected by them. It is a case for the application of the maxim, idem est non esse at non apparere. It applies to cases of negligence as well as of fraud, for the injurious consequences of both are not distinguishable.

We accept the legal fiction that the prior purchaser in effect "created" the ignorance of the subsequent purchaser. ${ }^{170}$ This holds true, of course, with the unrecorded instrument being definitive of the subsequent buyer's innocence and bona fides, only so long as the subsequent purchaser does not have some non-record reason to know of the competing claim. ${ }^{171}$

Similarly, some courts base this choice to allow subordination of the first purchaser's claim to title on the idea that the first purchaser is essentially "permitting the fraud" to occur. ${ }^{172}$ By not recording and leaving open the opportunity for bad grantors to conduct their dirty deeds and convey to unwitting subsequent purchasers, some theories hold that the first grantee is guilty of "constructive fraud" and consequently the first grantee is the one that in all fairness should bear the loss of not owning the property. ${ }^{173}$ Other courts reach the same result granting winner status to the ignorant bona fide purchaser based on an estoppel theory-first purchasers are estopped from claiming ownership because they failed to take advantage of the opportunities made available by the

\footnotetext{
168. See Rumsfeld Transcript, supra note 104.

169. Neslin, 104 U.S. at 439 (emphasis added).

170. See id.

171. Faris v. Finnup, 113 P. 407, 409 (Kan. 1911) ("Such a purchaser may assume the nonexistence of any instrument which has not been made valid against him in this manner [of recording]" but can be "deprived of the benefit of this assumption [by] information that a prior deed is in fact outstanding and unrecorded").

172. 1 PALOMAR, supra note $13, \S 17$.

173. Id.; Lessee of Henry v. Morgan \& Cox, 2 Binn. 497, 502 (Pa. 1810) (describing intent of bona fide purchaser protections in recording acts as "to protect innocent purchasers from suffering by the fraud or negligence of those, who had obtained prior conveyances from the same person, and omitted to have them recorded").
} 
law to protect their own interest, ${ }^{174}$ mainly by recording and giving public notice that would have defeated the ability for a subsequent purchaser to make an adverse claim. ${ }^{175}$

But it is really even more than just a mere assignment of responsibility that is supporting the courts' conclusions regarding priority. Instead, many contend that a first purchaser who does not record has simply failed to do what is necessary to become an owner, and that he has left an interest, indeed a power of sale, with the grantor until that first purchaser records. ${ }^{176}$ One must do more than just dole out money to pay for a conveyance to call himself the owner of what he bought. ${ }^{177}$

Here is how the idea flows: The law has created a type of semantic fiction to overcome the confounding confrontation with nemo dat that the recording acts create. According to the formalistic explanations for why one can sell land to $A$ and sell again later the same land to $B$, the grantor is empowered to do so whenever the first purchaser $A$ has not yet recorded because, by not recording, $A$ has yet to take the authority to sell away from the grantor. When the original grantee has yet to record, the original grantor has yet to lose his authority to convey to another purchaser. The next few paragraphs spell this rationale out further.

In notice and race-notice jurisdictions, the seeming lack of authority on the part of a grantor to sell to a second purchaser after already selling to someone else is simply not debilitating to such a sale. When such a thing happens, the subsequent purchasers maintain an ability to attain bona fide purchaser status. ${ }^{178}$ The problem with unrecorded deeds is that, in most jurisdictions, the original purchaser by failing to record has not yet converted the equitable title that he received (at the point of conveyance) into a legal title (which happens after conveyance and at the

174. The Washington Supreme Court explained this necessity of weighing between two innocents as follows:

When we apply the rule of comparative innocence, it is impossible to escape the conclusion that the judgment must be affirmed. As between two innocent persons, one of whom must suffer a loss, appellant is obviously the one who is responsible therefor. He failed to have his property correctly described in his deed and then failed to have it recorded. He failed to do as the ordinarily prudent and cautious individual does.... Appellant had ample opportunity to protect himself and did nothing. Respondent did everything that could be expected of it.

Cunningham v. Norwegian Lutheran Church of Am., 184 P.2d 834, 840 (Wash. 1947).

175. 1 PALOMAR, supra note $13, \S 17$.

176. Id. ("Grantees who fail to give notice . . leave the way open for their grantors to convey to others who have no notice of a prior transfer.").

177. See id.

178. See id. $\S 11$ (explaining the essential elements of a bona fide purchase). 
point the property is recorded-provided of course that there is not a competing legal title claim at that time). ${ }^{179}$ That reality means that until that point in time when the conveyance is recorded, the grantee is leaving the grantor free to exploit the gap and gives the dirty grantor an opportunity to try to pass the same title to another, i.e. the grantor "retains, by force of the statute, a power to defeat the conveyance, if not recorded, by a subsequent conveyance to another."180

Consider the explanation of the Pennsylvania Supreme Court in an opinion that was required to wrestle with this very issue:

For instance, in the typical recording statute situation, a grantor sells land to a grantee who does not record the deed; then, a subsequent buyer purchases the same land from the same grantor as the original grantee and this subsequent grantee records his deed before the first grantee. The subsequent grantee does not have [so-called] "legal title" within the Appellant's definition because at the time the land was sold to him, the grantor did not have legal title to give such right. Yet, notwithstanding the fact that he does not have "legal title," he is a bona fide purchaser if at the time of the sale he was without notice of an adverse interest and value was given for the purchase of the land. As evidenced here, imposing a requirement of "legal title" to the definition of a bona fide purchaser would nearly render the recording statute useless. We, therefore, find no merit in Appellants' argument.

In essence, the grantor retains a "power of sale" despite the seeming lack of authority (because he has already sold it once). ${ }^{182}$ His authority, in that sense, is not dissolved until the grantee records. ${ }^{183}$

And, indeed, if one looks at it in this way, then a bona fide purchaser does not "take" anything away from a prior purchaser who did not

179. 5 TIFFANY, supra note $14, \S 1262$ ("[A] deed after it is delivered and before it is recorded operates as a contract to convey, and passes to the grantee an equitable title and right to the formal legal title ....").

180. Id. As Professor Aigler stated:

The Recording Acts of the various states differ in their phraseology, but the substance of most of them may be stated in this way: Certain instruments as to certain people are ineffective unless the statute is complied with.... The effect of the statute really is that the person claiming under the instrument in question by his failure to observe the direction of the statute confers upon the party who executed the instrument ... a sort of statutory power to displace the interest vested by the execution of the instrument. This power may be effectively exercised only in favor of those specified in the statute, usually subsequent purchasers and incumbrancers. ... The failure to record simply puts someone into position to divest that interest.

Aigler, supra note 9, at 415.

181. Roberts v. Estate of Pursley, 718 A.2d 837, 841 (Pa. 1998) (citation omitted).

182. 1 PALOMAR, supra note $13, \S 17$ (" $[\mathrm{S}]$ o long as [a conveyance] is not recorded the purchaser leaves in his grantor both the record title and a power of sale.").

183. Id. 
record; the prior purchaser simply did not do what was necessary to effectuate their interest. ${ }^{184}$ Professor Ralph Aigler provides the following crisp example:

So in the simplest sort of case involving the application of the Recording Act - a deed to $B$ and a later deed of the same premises to $X$, a bona fide purchaser - if $B$ recorded, $X$ gets nothing, not because he took with notice, but because $B$ had omitted nothing in the saving of his common law priority,- - there was no power in the grantor to displace the first grantee's interest; and if $B$ had not recorded, then he loses out not because $X$ took without notice but because $B$ 's failure put the grantor into position under the statute to displace $B$ 's vested interest in favor of $X$.

Thus, by not acting responsibly, the prior purchaser has not done enough to protect his rights and concomitantly strip the grantor of his power to convey to another.

It is precisely the "incentivization" of recording aimed toward every holder of an interest in property (including and especially those that are first in time to receive it) that is intended within the structure of the recording acts. ${ }^{186}$ Through what might be called the "completion of the conveyance process" that recording provides (and the benefits that recording brings through protection for title), the prior purchaser avoids the consequences of displacement by disempowering the grantor from effectively selling again.

Finally, out of responsibility comes opportunity. Rather than being seen as simply designed as a means for making it harder for first-in-time purchasers to protect their interests against bona fide purchasers (and consequently easier for bona fide purchasers to make their claim), the recording system serves a concurrent function by opening up opportunities for first-in-time purchasers to add a valuable attribute to their property title that did not exist in the common law, pre-recording

184. As Professor Rogers explains the failure on the part of the first purchaser to fully establish her rights:

[I]t is a bit misleading to say that someone is a bona fide purchaser and therefore takes

free of a prior claim. Qualifying as a bona fide purchaser may be a necessary condition for invocation of a rule cutting off prior claims, but the basis of such rules is usually that the prior interest was itself not properly effectuated. James Steven Rogers, Negotiability as a System of Title Recognition, 48 OHIO ST. L.J. 197, 203 (1987).

185. Aigler, supra note 9 , at 415.

186. Pomeroy, supra note 40, at 141 (discussing universality of recording acts and their design to incentivize "creditors and claimants to record publicly any claims they might have to real property"). 
environment.

The recording laws make it easier for first-in-time purchasers to establish a verifiable, certain, and enforceable claim to property in a manner that actually deters litigation by adverse claimants because of the certainty and authority of the recording system. ${ }^{187}$ For little cost, they can provide great protection. Recording and its consequences also decrease litigation costs because the first-in-time purchaser need not prove his case in an exhaustive evidentiary battle against adverse claimants. Even when he could win such an evidentiary battle, the prospect of litigation alone has adverse effects on the market for property. For example, even when he could prove his case, the first-intime title claimant would need to expend substantial costs before getting to a judicial resolution in his favor. As Professor Dan Schechter explains, "The [recording] system promotes certainty in the transfer of interests in real property by encouraging parties to avoid costs by recording and making diligent inquiry," and, "[i]n turn, certainty enhances the price that transferees are willing to pay for property, thus enhancing the value of the property itself." 188 So, we return again to the point that the law favors those things that encourage recording because recording increases the value of property.

There are several ways that uncertain or high-risk title can inhibit the market for property or add unnecessary costs, including where "prospective transferees might avoid acquiring property interests altogether, might purchase more insurance against the risk of loss than they otherwise would, might require extensive guarantees from the grantor, or might take other measures to cushion themselves against loss." unproductive and inefficient costs, the recording rules should aim to do so. ${ }^{190}$

Thus, we again return to the idea that multiple beneficiaries of the recording system must make certain investments and buy into the system, and when they do they will be guaranteed rewards. A consequence of the institution of recording statute regimes certainly

187. Palestina, supra note 13, at 995 ("[A] system of public recordation should provide both security and stability for the property rights of owners.... [I]t should facilitate the transfer of property between buyers and sellers such that property remains in commerce.").

188. Schechter, supra note 62, at 120 (footnote omitted).

189. Id. (footnote omitted).

190. Rogers, supra note 184, at 216 (speaking generally about all types of title registration or recording, and stating that " $[\mathrm{t}] \mathrm{he}$ goal of a system of title recognition should be to provide assurance of title to purchasers by enabling them to discover the existence of adverse claims before purchasing the property"). 
includes protecting bona fide purchasers that would otherwise lose in a first-in-time system and who were the subject of dirty deed transfers on the part of unscrupulous or mistaken grantors, but that is not the only brilliance of the design. The purpose was never to make it easier to displace first-in-time purchasers. In fact, it empowers first-in-time claimants with a weapon-recording - that they also did not have in a common law priority system to shut out altogether potential adverse subsequent purchasers.

It is evident that this other purpose of the recording laws is to shrink the pool of potential, legitimate bona fide purchasers and decrease the number of competing claims that need to be resolved in litigation. By recording, a purchaser is effectively shutting others out from claiming title or achieving the status necessary to claim title. The net plus for the market for property from fewer title contests and fewer title contestants cannot be ignored.

Any improvements that can be made that would further shrink the pool of potential, legitimate bona fide purchasers by injecting information helps get us closer to the goal of protecting first-in-time purchasers and consequently supporting achievement of the nemo dat ideal where one cannot sell the same property to more than one purchaser. That is the goal of TINTS, for example, as will be further explained in Part V. Such innovations in information-generating mechanisms would not be designed to shrink the pool of protected buyers through means that punish any innocents, but instead these innovations would be aimed at making it harder to be innocent by making it easier to access more complete information regarding competing claims to title.

For each of the reasons discussed above, recording one's interests has become a legal responsibility with real consequences flowing from one's failure to fulfill that responsibility. For any purchaser of property seeking to avoid subordination of his interests, recording just makes sense. By recording the title conveyed to it, a purchaser has the ability to make it much harder for the grantee to commit fraud because his dirty deeds will be transparent and easily revealed upon an inspection of the records. ${ }^{191}$ Once a property is recorded, the ability to successfully carry

191. Schechter, supra note 62, at 110-11. Professor Schechter makes this point well when he states that:

[W]ithout a recording system, a grantor could more easily convey the same interest in real property a number of times and then abscond with the consideration given by the transferees, leaving them to fight over the property. In contrast, a transferee who can record his interest gives notice to subsequent prospective transferees, thus protecting 
out a fraudulent re-conveyance without exposure and liability is severely diminished. Such fraud deterrence is one of the important rationales underlying the development of recording laws and bona fide purchaser protections. ${ }^{192}$

\section{Setting the Bar: Aiming for a Nemo Dat Ideal, While Accepting Property Law Pragmatism But Only When Necessary}

At common law and with first-in-time rules applicable, nemo dat carried the day. ${ }^{193}$ Between equal equities, the first-in-time would win, ${ }^{194}$ which means too that the first-in-time purchaser would win against a subsequent purchaser even if that subsequent purchaser did not have notice of the prior claim. ${ }^{195}$ That system for establishing priority most closely approximated an adherence to a pure application of the nemo dat principle.

The recipient of a conveyance after property had previously been conveyed would lose under common law priority rules because the grantor would be attempting to sell more than was lawfully available to him to sell. All of that changed with the recording acts, each of which essentially opens a window that can sometimes allow a situation in which property sold once can effectively be sold a second time by the same grantor. ${ }^{196}$ Our policies shifted over time to reflect an Id.

himself and other grantees against the grantor's fraud.

192. Id. at 112 ("[T] subsequent transferees would be protected, while the certainty rationale partly explains why some unrecorded transfers not involving fraud are nevertheless invalidated.").

193. 5 TIFFANY, supra note $14, \S 1257$ (describing nemo dat at common law and explaining that the recording acts are a "very considerable departure from" the rule that "one who has no title cannot transfer title to another, one who has transferred his legal estate to one person cannot thereafter detract from the effectiveness of such transfer by undertaking to transfer it to another"); Ortman, supra note 21, at $465 \mathrm{n} .18$ ("The theory behind the common law doctrine was that the grantor had nothing left to convey to the later grantee." (citing 1 R. \& C. PATTON, PATTON ON TITLES $\S 8$ ( $2 \mathrm{~d}$ ed. 1957))).

194. Neslin v. Wells, 104 U.S. 428, 441 (1881) (“[T]he maxim quoted in support of this claimqui prior est tempore potior est jure —only applies in cases in which the equities are equal.").

195. A leading treatise states the rule:

As between interests or claims of a purely equitable character, that is, enforceable in equity alone, the rule, as generally stated, is that between equal equities priority of time will prevail, that is, they will rank according to their time of accrual. And the fact that the later equity is acquired without notice of the earlier equity is ordinarily immaterial in this connection.

5 TIFFANY, supra note 14, § 1260 (footnote omitted).

196. Plank, supra note 7, at 449 (providing a useful hypothetical to explain that "a transferor that has previously conveyed to a transferee all of the transferor's interests in a property item may nevertheless be able to grant to a second transferee an interest in a property item that the transferor 
understanding that recording systems are market-facilitating. They assist with transactions by providing information that all who wish to engage with the property need in order to make informed and economically prudent decisions regarding that property. ${ }^{197}$

So, although nemo dat stands at the foundation of our principle of finite property, limited rights, and identification of private ownership, we nonetheless have decided that a well-functioning system cannot operate if we accept a pure nemo dat regime. I contend that the American system strives through rule discipline to achieve as close to a nemo dat reality as possible while recognizing pragmatically that a market in the sale of property cannot function with strict and unbending adherence to the nemo dat principle. Thus, exceptions to applying nemo dat must be made in the real property transfer system as well as in similar commercial enterprises in personal property, goods, securities, and other types of owned interests in which certain protections for good faith ${ }^{198}$ or bona fide purchaser status become recognized exceptions to nemo dat. ${ }^{199}$

does not have" when certain nemo dat exceptions apply, including when "[t]he operation of the recording acts and the failure of $A$ to protect his interests under the recording acts give $O$ the power to transfer to $B$ an interest in property- $A$ 's fee simple in Blackacre- that $O$ did not have") (emphasis added).

197. Korngold, Legal and Policy Choices, supra note 128, at 743-44 (explaining the broad public need for access to title information because "[c]urrent and potential participants in land transfer and finance transactions need information so markets can operate efficiently and fairly, thus benefiting those particular players as well as society").

198. Plank, supra note 7, at 442-443 (discussing good faith purchaser principles as exceptions to nemo dat); Steven L. Schwarcz, Intermediary Risk in a Global Economy, 50 DUKE L.J. 1541, 1573-74 (2001) ("Commercial law generally respects nemo dat (and by extension the axiom) with only limited exceptions: that bona fide purchasers of goods and holders in due course of negotiable instruments are not necessarily subject to defenses and encumbrances to which the transferor is subject.") (footnote omitted); $c f$. Levitin, Finding Nemo, supra note 5, at 124-125 (explaining good faith purchaser defense in commercial law-comparable to bona fide purchaser status in real property law-as "an exception to nemo dat").

199. Rogers, supra note 184, at 201 (stating similar bona fide purchaser rules exist in negotiable instruments law, which functions much like "other legal techniques for the recognition of interests in property, such as the recording system or title registration systems for interests in realty, the filing system under Article 9 for security interests in personal property, or the certificate of title system for motor vehicles"); $i d$. at 198 (discussing "as among the most well-settled principles of commercial law: the principle that by virtue of the holder in due course rules a bona fide purchaser of a negotiable instrument takes it free from all adverse claims"); see also id. at 199 ("[D]istinguishing characteristics of negotiable instruments" include that "a bona fide purchaser can acquire good title even from a thief" (citing 8 W. S. HOLDSWORTH, A History OF ENGLISH LAW 113-14 (1926))). Professor Levitin compares negotiability in commercial law to real estate transfers explaining that:

Nemo dat is the default rule for property transfers, but there is a competing commercial law paradigm: negotiability. Negotiability is usually thought of in terms of Uniform Commercial Code Article 3 (negotiable instruments), but it appears in other areas of law, including U.C.C. Article 2 (sales), U.C.C. Article 7 (warehouse receipts and bills of lading), U.C.C. Article 8 (investment securities), U.C.C. Article 9 (secured loans), and the law of real estate mortgages and titles. The essential characteristic of negotiability is 
Whether in relation to the transfer of real property or commercial assets, the law must act pragmatically when choosing a winner among multiple claimants. ${ }^{200}$

The primary exception to the nemo dat principle in real property law is the protection of bona fide purchasers' claims to title when they purchase property for value without notice of prior claimants. ${ }^{201}$ The bona fide purchaser rule is designed with definiteness and predictability in mind, each contributing to investment in property. ${ }^{202}$ The purchaser must set forth on a course of due diligence hoping he will find no adverse claims, ${ }^{203}$ yet thankful, in a way, if he does find evidence of an adverse claim. He will be thankful if he finds a valid prior titleholder because he can move on and elude a potential property pitfall that may have ensnared him. Absent the recording system and the ability to find the claimant, he might have been buying something he cannot ever have or at the very least he would have faced a risk of potentially costly litigation to try to keep title to it.

The bona fide purchaser is given priority status, superior to the prior claim, thereby subordinating the rights of the earlier purchaser. ${ }^{204}$ While the notice and race-notice recording regimes across the various states continue to recognize the bona fide purchaser rules, those rules are not dependent on such statutes. In fact, the bona fide purchaser protectionor, to put it more precisely, the inability for a subsequent purchaser to

that only limited defenses travel with property, and thus a transferee can receive more than the transferor had - a property right free of certain defenses against its enforcement. This means that there is some level of negotiability in any area of law with a good faith purchaser defense.

Levitin, Finding Nemo, supra note 5, at 90 (footnotes omitted).

200. Davis, supra note 4, at 196 ("The nemo dat rule, however, is subject to important exceptions in favour of good faith purchasers for value without notice in cases involving currency; negotiable instruments; sales by sellers with voidable title; sales by sellers, buyers, or factors in possession; and situations in which the true owner is estopped from denying the authority of the intermediate transferor."); Levitin, The Paper Chase, supra note 5, at $641 \mathrm{n} .14$ (citing several doctrinal examples to conclude that: "The UCC is replete with provisions that allow a good-faith purchaser to take better title than the seller had, but these are distinct situational exceptions to the nemo dat rule. . . Similarly, there are exceptions to nemo dat in property law.").

201. Bjerre, supra note 5, at 333 ("Protecting third parties without notice can be viewed as an exception to the principle of nemo dat quod non habet.... This principle ... dictates that if an owner transfers widgets to one buyer, she generally may not thereafter transfer the same widgets to a later buyer.").

202. Owen L. Anderson \& Charles T. Edin, The Growing Uncertainty of Real Estate Titles, 65 N.D. L. REV. 1, 46 (1989) (stating bona fide purchaser "rule is grounded in a strong public policy to keep land titles definite in order to protect investment and encourage trade").

203. See Fisher, supra note 19, at 451. Professor Fisher made the point almost poetically when he stated that "title work involves looking through the appropriate records in search of the unexpected in hopes that you will not find it." Id.

204. See Rogers, supra note 184, at 204. 
take title to property over a prior claimant if that subsequent purchaser has notice of the prior claimant's rights - existed before the recording acts were instituted in the United States. ${ }^{205}$ The rules that one with notice has no valid equitable claim were enforced then as a matter of equity and continue to be enforced alongside the recording acts on the same equitable bases. ${ }^{206}$ Nonetheless, bona fide purchaser rules have also developed as the heart of most modern day recording systems. ${ }^{207}$

This "fundamental" rule ${ }^{208}$ for protecting subsequent bona fide purchasers without notice is guarded vigorously in the development of legal doctrine. ${ }^{209}$ As one leading treatise puts it, "[t]he law goes a great way in protecting the title of a purchaser for value without notice or knowledge of any defect in the power of the vendor to sell," 210 and as another set of authors opined, bona fide purchasers are a "favorite child" of the law. ${ }^{211}$ But, similar to the doctrine of "unclean hands" in contract law, once it is established that the subsequent purchaser has notice of the dirty deed being perpetrated, then his hands are also sufficiently unclean that the law will not choose his claim over a prior equitable interest. ${ }^{212}$

The exceptions to nemo dat in the recording acts are designed to

205. 5 TIFFANY, supra note $14, \S 1258$ ("If the equitable interest or claim is first created, the question whether one who subsequently acquires the legal title takes free from the equitable interest or claim, will ordinarily depend on whether he is a purchaser for value without notice thereof, courts of equity refusing to enforce the prior equity as against such a purchaser.").

206. Id.

207. Schechter, supra note 62, at 109 ("The search for the goals of the recording system begins with a simple observation: all real property recording statutes provide that an unrecorded transfer of an interest in real property may be invalidated by certain subsequent transferees of conflicting interests.") (footnote omitted).

208. 5 TIFFANY, supra note $14, \S 1258$ ("This principle, that equitable relief will be denied as against a purchaser for value and without notice, who has acquired the legal title, is fundamental ....”)

209. Kumar v. Bay Bridge, LLC, 903 N.E.2d 114, 116 (Ind. Ct. App. 2009) ("The theory behind the bona fide purchaser defense is that every reasonable effort should be made to protect a purchaser of legal title for a valuable consideration without notice of a legal defect." (quoting S \& S Enters. v. Marathon Ashland Petrol., LLC, 799 N.E.2d 18, 23 (Ind. Ct. App. 2003))) (emphasis added).

210. 5 TIFFANY, supra note $14, \S 1552$ (discussing priority rules in the recording of mortgages); see also id. $\S 1258$ (describing reason to award title to subsequent bona fide purchaser without notice as resting on the fact that it is "not unconscientious for him to retain it"); Ortman, supra note 21, at $466 \mathrm{n} .23$ ("The theory underlying the Texas recording statutes is that until the grantee records his conveyance as required by statute, a power is left in the grantor to displace the prior conveyance." (citing Dwight A. Olds, The Scope of the Texas Recording Act, 8 Sw. L.J. 36, 46 (1954))).

211. Anderson \& Edin, supra note 202, at 45 ("Traditionally, the bona fide purchaser has been a 'favorite child' under the law.").

212. 5 TIFFANY, supra note $14, \S 1258$ (stating notice of prior equitable claim makes one "unconscientious"); id. § 1283 (explaining the debilitating effect of notice on a subsequent purchaser's ability to make a claim for property is often based on "the theory that one taking a conveyance with the purpose of impairing prior rights in another of which he has notice is guilty of fraud"). 
incentivize recording because of the high level of certainty and protection that recording provides to those that "perfect" their claim by doing so. ${ }^{213}$ There is a very valuable reward to recording that makes it worth the minimal effort and low cost. Recording rules promote efficiency and certainty because by recording an owner gets the enforceability that comes with public notice of a claim and subsequent purchasers are able to discover the claim at a relatively low cost. ${ }^{214}$ The entire system (including components related to nemo dat and its exceptions) aids a potential purchaser in identifying the strength of the rights he is acquiring, allows a seller to confirm that he owns what he thinks he owns, and bolsters confidence among potential purchasers that the claimed owner has the legal authority to sell what he is attempting to sell. $^{215}$ We expect that, with increased reliance through more effective verifiability mechanisms, property will be more secure, ${ }^{216}$ and we anticipate that recording will also consequently inject more fairness. Together, these functions of recording facilitate property's more agile movement in commerce. ${ }^{217}$

But, it should be clear that by recognizing exceptions to nemo dat we create "opportunit[ies] for mischief" and effectuate the dirty deeds of "bad actor[s].", We have hence been required to rely on second-best solutions to counteract these risks rather than the arguably first-best option of applying nemo dat.

We might fashion the dilemma as one where the first-best system would involve full application of the nemo dat principle (consequently avoiding or at least mitigating the harmful effects of the bad actors, fraudulent activity, and incomplete information that we actually see in the world). ${ }^{219}$ While we would prefer first-best solutions that might

213. See ANDERSON \& BOGART, supra note 17, at 548 (explaining the "purpose of recording statutes is to strongly incentivize" recording); cf. Plank, supra note 7, at 450-51 (discussing nemo dat and recording of security interests).

214. Id., at 450 (explaining the consequences for securities markets for similar nemo dat rules and exceptions).

215. Id. at 505 (explaining the assurances to multiple market participants that "[b]oth nemo dat and the exceptions to nemo dat enacted in the real estate recording acts and Article 9, such as the Filing Priority Principle, are intended to provide").

216. Id. at 450 (explaining recording acts "override[] nemo dat ... to promote the "security of property"').

217. Mitchel McInnes, Enrichments and Reasons for Restitution: Protecting Freedom of Choice, 48 MCGILL L.J. 419, 453 n.137 (2003) ("[T] he law wishes, as a matter of fairness and commercial reality, to occasionally create exceptions to the general rule of nemo dat quod non habet.").

218. Levitin, Finding Nemo, supra note 5, at 90-91.

219. Plank, supra note 7, at 455-56 (categorizing nemo dat in a manner consistent with the idea that it is a first-best option). 
prevent the sale of previously conveyed property, in light of the principles supporting the nemo dat exceptions, we must be satisfied with second-best solutions to control, deter, and punish wrongdoers-while using the second-best solutions to also make those that necessarily must lose any claim to a finite piece of property (for which we can only choose a single winner to whom to award possession and ownership) as close to whole as possible.

Second-best rules accept the necessity of a relaxation of the first-best preferences. ${ }^{20}$ Among these is the protection of first recorded interests. Those rules attempt to approximate the conditions that would reach the nemo dat ideal. Deed covenants and warranties of title and similar means of title assurance also exist as second-best measures to protect against loss from multiple sales of the same property. ${ }^{221}$ A variety of other anti-fraud devices are available in private and criminal law. ${ }^{222}$ Knowing that we cannot make every purchaser of property whole in the face of multiple conveyances of the same property, the system satisfies itself with the ability to punish and deter those that create title chaos through the passing of dirty deeds using civil and criminal liability. ${ }^{223}$

Furthermore, the reliance on the recording systems to achieve our preferences is itself a second-best option. If one desires to award title to all good faith purchasers (including the person who purchases the property first) and to prevent owners from selling property twice, strict

220. Lawrence B. Solum, The Aretaic Turn in Constitutional Theory, 70 BROOK. L. REV. 475, 486 (2004-05) (describing the ideas behind first-best or preferred systems that because of unattainability of control over all variables necessitates acceptance of a second-best system with application of second-best values (citing R.G. Lipsey \& Kelvin Lancaster, The General Theory of Second Best, 24 REV. ECON. STUD. 11 (1956))).

221. See SINGER, supra note 13, § 11.4.3, at 534-36 (explaining title covenants); see also Charles B. Sheppard, Assurances of Titles to Real Property Available in the United States: Is a Person Who Assures a Quality of Title to Real Property Liable for a Defect in the Title Caused by Conduct of the Assured?, 79 N.D. L. REv. 311, 314 (2003) (describing several types of title assurance beyond recording including covenants or warranties of title in contracts of sale and deeds; abstracts of title; attorney opinions, along with corresponding liabilities; and title insurance).

222. Schechter, supra note 62, at $111 \mathrm{n} .26$ ("The relative importance of the recording system as a vehicle for preventing or deterring fraud may have been diminished somewhat with the growth of other anti-fraud devices such as the Uniform Fraudulent Conveyance Act, the Uniform Fraudulent Transfer Act, civil damages for fraud, and criminal penalties for fraud.").

223. See, e.g., Smith v. State, 98 So. 586, 588 (Fla. 1923) (upholding guilty verdict in "false pretenses" case where seller made representation that " the property was free and there was nothing against it,' when in fact he had previously joined with his wife in executing a mortgage on the property ... for which he would be criminally liable if he obtained from another any money or other property thereby"); $c f$. State v. Banks, 211 S.E.2d 860, 862 (N.C. Ct. App. 1975) (upholding conviction when purchaser replied on representations and defendant signed and delivered deed and accepted purchaser's money knowing that he was falsely representing that the property was free of encumbrances). 
adherence to nemo dat may be the first-best option. But that requires honesty and non-fraudulent-indeed even non-mistaken-behavior so that property is never sold more than once to more than an initial purchaser. It would also require that there is never an innocent subsequent purchaser who purchases without notice of a competing claimant. The necessary conditions for achieving the desired results do not exist and therefore negate choosing the first-best solution of strict adherence to nemo dat as a means for achieving those results. ${ }^{224}$ Because these elements may be lacking in one way or another in the real world, strict adherence to nemo dat is not the most viable means to accomplish such desires. Hence, we adopt the second-best option seen in recording statutes that seek to motivate all purchasers to take acts (beyond just the purchase itself) to protect their interests, and, in particular, we set priority rules that may deviate from nemo dat-like first-in-time principles as our second-best options to more closely accomplish the desired ends. ${ }^{225}$ The recording act exceptions to nemo dat, joined with alternative enforcement mechanisms to deter bad behavior and make whole the innocents, operate as a system of second-best rules.

Again, we must admit that these exceptions technically permit a transferor to transfer something "that the transferor no longer has because the transferor previously transferred that interest to a prior transferee, with the result that the original owner or a prior transferee may lose some or all of the same property interest." 226 The recording acts specifically dilute the effectiveness of nemo dat in this regard. ${ }^{227}$

The exceptions to nemo dat are necessitated by the existence of a market failure in the production and availability of information. We only need to protect subsequent bona fide purchasers and subordinate first-intime titleholders because of imperfect information flow regarding the first sale. If we can find ways to provide a greater-sized repository of accurate information accessible at a low enough cost, we are achieving a more efficient market.

224. Cf. Daniel E. Schoeni, Second-Best Markets: On the Hidden Efficiency of Defense Offsets, 44 PuB. CONT. L.J. 369, 397-98 (2015) (providing some very useful examples of real-world secondbest alternatives to "blackboard"-based first-best options).

225. Id. at 397 (citing Making the Second Best of It, THE ECONOMIST (Aug. 21, 2007), http://www.economist.com/blogs/freeexchange/2007/08/making_the_second_best_of_it).

226. Plank, supra note 7, at 442-43 (discussing exceptions to nemo dat "which apply in a variety of real and personal property regulatory regimes" as enabling this result).

227. Nelson v. Hughes, 625 P.2d 643, 647 (Or. 1981) (describing a case involving two sales of same property, and Professor Corwin Johnson's conclusion that "one of the purposes of the recording acts is to modify the traditional common law doctrine that subsequent purchasers, no matter how bona fide, get no better title than the transferor owned"). 
For these reasons, we should always be looking for ways to shrink the application of the exceptions without necessarily changing the criteria for eligibility to claim the exception. The goal should be to make fewer claimants fit the criteria to except application of nemo datsomething which is best accomplished by injecting information accurately, more often, and at quicker paces than we are doing today.

While exceptions to it are common, ${ }^{228}$ the law still accepts nemo dat as the baseline ${ }^{229}$ and the norm from which we carve out exceptions. ${ }^{230}$ Because nemo dat should be that baseline for identifying the legitimacy of land transfers, we should manage property rules to most closely maximize our ideal adherence to it. ${ }^{231}$ We should presume in favor of (or, as some might say have a "thumb on the scale" in favor of) application of nemo dat wherever practical and efficient. ${ }^{232}$

\section{A PRELIMINARY PROPOSAL FOR EXPLOITING THE UNDERUTILIZED UTILITY OF INQUIRY NOTICE- \\ TINTS: THE TITLE-RELATED INQUIRY NOTICE TRIGGERING SYSTEM}

The goals of the recording system should include accuracy, completeness of information, speed in uploading facts and events into public memory and in transmission of information, and the utmost protection and enforceability of interests in land. ${ }^{233}$ If we could protect first-in-time takers better by concomitantly decreasing those eligible for bona fide purchaser status simply because we give more people more information that exhibits a higher degree of completeness and accuracy, it seems that we would achieve those goals.

The utility and desirability of record notice is a given, and it should be encouraged at every step. Every prudent purchaser of property must be encouraged to record and we should find every way possible to make that system more accurate, efficient, user-friendly, and quick-on-the-

228. Smith, supra note 11, at 2121 ("In practice, exceptions to nemo dat apply often, if not most of the time" especially as a result of the recording statutes) (emphasis added).

229. Id. at 2123 ("[N]emo dat . . covers a heterogeneous set of circumstances that reflect its being the general baseline, however compromised it may be in practice.") (emphasis added).

230. Id. at 2122 (explaining that this baseline approach allows the exceptions to be grouped within "the generality of good faith purchase as a unitary rule" capturing the essence of most exceptions to nemo dat including those applicable to bona fide purchasers).

231. Levitin, Finding Nemo, supra note 5, at 99 ("Nemo dat is the baseline rule of property transfers.") (emphasis added).

232. Plank, supra note 7, at 462 ("Absent a good reason to overrule nemo dat, nemo dat should prevail.").

233. Korngold, Resolving, supra note 18, at 1564 (“[R]ecording acts and related rules" focused on accuracy and accessibility of information to protect interests in land). 
upload to the public space. Nonetheless, inquiry notice is an additional and underexploited protective tool, especially during gap periods between a title commitment and actual indexing and recording.

The risk that a grantor will sell dirty deeds during such gaps is real. As one author explains, "[t]he recording process, from submission to recording, takes time, and there is often a delay, or gap, between when the document is submitted to the recorder's office and when that document is officially recorded and indexed." ${ }^{234}$ While title insurance may exist during such gaps, ${ }^{235}$ it is expensive, incomplete, and does not actually deter the bad behavior or inject information into the system that can prevent the inefficient passing of, and payment for, dirty deeds. ${ }^{236}$ It is especially during these gaps when the recording system and first-intime purchasers are most vulnerable and when we can easily see prime opportunities for multiple sales of the same property in violation of the nemo dat ideal.

Often for good reasons and sometimes in spite of itself, real property law has not been known as a fast adapter to change or the first to embrace innovative techniques. ${ }^{237}$ But when a good idea comes along that can effectuate what are time-honored, preferred outcomes, like the minimization of fraudulent transfers and finding ways to achieve full application of the nemo dat principle whenever possible, that idea should get a hearing. ${ }^{238}$

234. Jessica Kopplin Kranz, Note, Expedition E-Recording, First Stop URPERA: How Universal E-Recording Under URPERA Could Revolutionize Real Estate Recording in the United States and Why It Should, 13 MINN. J.L. SCI. \& TECH. 383, 387 (2012); see also Justin L. Earley \& James B. Jordan, Understanding Interim Title Insurance Documents (With Forms), 27 No. 2 PRAC. REAL EST. LAW. 41, 42-43 (2011) (discussing the very real risks associated with potential adverse claims being filed in the gap period, possibly subordinating interests of a titleholder).

235. John C. Murray, Attorney Malpractice in Real Estate Transactions: Is Title Insurance the Answer?, 42 Real Prop. Prob. \& TR. J. 221, 236 (2007) (discussing American Land Title Association forms provisions for gap insurance and explaining that the "gap risk occurs when a title policy states an effective date, but the deed or mortgage is actually recorded later, which raises the possibility of an intervening lien attaching and being recorded before the deed or mortgage, thereby cutting off the priority of the insured interest").

236. Grant S. Nelson \& Dale A. Whitman, Adopting Restatement Mortgage Subrogation Principles: Saving Billions of Dollars for Refinancing Homeowners, 2006 B.Y.U. L. REV. 305, 362 (2006) ("If lenders cannot get title insurance expenses down to acceptable levels, they are likely to dispense with title insurance entirely, becoming self-insurers.").

237. See, e.g., Ann M. Burkhart, Freeing Mortgages of Merger, 40 VAND. L. REV. 283, 284 (1987) ("Change in real property law often occurs with glacial speed. This rate of change in part reflects the normal inertia of established law. A more complete explanation, however, is the innate conservatism connected to a commodity that once was the primary source of wealth and power.").

238. Szypszak, Real Estate Records, supra note 15, at 39 (noting that we should look for "opportunities for improvement, especially in a market and technological environment that could not have been envisioned when the present system was developed"). 
We should be asking innovators to harness technology and the power of inquiry notice to inject information and better preserve the rights of first-in-time purchasers. Recording systems in the United States are based on out-dated methods that fail to capture the benefits of technology, so every proposal designed to capitalize on available and emerging technology to better distribute title information is worth considering. ${ }^{239}$ Many have already recognized that computerized recording systems themselves can decrease information-gathering costs and reduce errors in a way that shrinks the pool of legitimate bona fide purchasers. ${ }^{240}$ Although some efforts are being made to use technology to improve the recording system, it is in constant need of modernization. ${ }^{241}$

There is an opportunity to fill gaps in recording with the type of information that can trigger inquiry notice-an under-exploited tool available to every first-in-time purchaser to protect their interests above and beyond the records office. This Part sketches the basic outline of a system I will call TINTS - the "Title-Related Inquiry Notice Triggering System."

The reform envisioned by TINTS is to provide a computerized mechanism for early public warning of a title claim even before any such claim is recorded and indexed in the public records office. In other words, because it will not constitute any type of official "record," the information provided by TINTS is something short of constructive notice. Instead, it is something less formal because it is only a triggering

239. See Dale A. Whitman, Are We There Yet? The Case for a Uniform Electronic Recording Act, 24 W. New ENG. L. Rev. 245, 246-50 (2002) (discussing the mechanics of recording, with analysis of reform proposals and prospects for and concerns with such efforts); see generally Dale A. Whitman, Digital Recording of Real Estate Conveyances, 32 J. MARShaLl L. REV. 227 (1999) (identifying a wide range of issues that need to be addressed in order to implement a digital recording system).

240. See, e.g., Martin B. Cowan, Introducing Twentieth-Century Technology to Real Estate Recording Practices (Before the Twenty-First Century Arrives), 28 REAL EsT. L.J. 99, 120-21 (1999) (discussing streamlining and efficiencies that are possible by harnessing technology and why "[w]ith today's technology, there is no reason to continue using such time-consuming and frustrating procedures" as we have for hundreds of years in records offices); see also Bayer-Pacht, supra note 17 , at 358, 369 (discussing the utility of "computerized systems" that "serve the same underlying purpose as" recording doctrines that have an ease that make it less necessary to protect subsequent purchasers because there will be fewer risks undiscoverable or "irregularly recorded deeds"); see also UNIF. REAL PROP. Elec. RECORding ACT (UNIFORM LAW COMM'N 2004), http://www.uniformlaws.org/Act.aspx?title=Real\%20Property\%20Electronic\%20Recording\%20Act.

241. Korngold, Legal and Policy Choices, supra note 128, at 740-41 (discussing the current property recording system as still paper-based but improving with the growth of "technology to make the recording system more efficient, more transparent, and less costly," and discussing developments in electronic signatures law as furthering the efforts); Marsh, supra note 124, at 20-24 (discussing improving ways to find and search property records). 
mechanism for further inquiry. It is also designed to have the advantage of providing information to the market more immediately than any type of official "notice" of an actual conflict in title while also raising enough concern that inquiry notice standards will apply even if what is revealed in TINTS cannot be deemed record or constructive notice. The system could be designed so that information can be both instantly uploaded and examined through a smart-phone application and internet website.

The point would be to allow purchasers to notify the world of the existence of their title claim to a particular piece of property immediately upon the completion of a conveyance from the grantor. The claim would be up for inquiry notice prior to the completion of posting of record notice in the records office. In this sense, it might be seen as operating during the pendency of the recording in a manner similar to the way lis pendens works for providing notice of pending litigation over claims of interest in real property. ${ }^{242}$ Exposure of claims has long been the goal of the title systems and in that sense, TINTS can, like recording itself, serve as a notoriety-assistance mechanism. ${ }^{243}$

As a matter of due diligence, all purchasers of real property would be required to check TINTS to see if any others have claimed an interest in the property, separate and apart from what is yet available in the records office. This could rise to the level of accepted "due diligence" by custom (which obviously might take some time but is a real possibility because courts have consistently recognized that customs can ripen into duties). ${ }^{244}$ Or, rather than waiting for custom to develop, a statutory mandate might be enacted that makes it a requirement for all purchasers to check TINTS as a prerequisite to eligibility for bona fide purchaser status. Thus, TINTS could operate as a private system, as a private system with a public mandate, or as a public system with a public mandate.

What constitutes due diligence under the law will be shaped by the ease and availability of information and the technology to deliver it. As one court recently explained on the question whether purchasers in that

242. Cf. Goldstein v. Gold, 483 N.Y.S.2d 375, 377-78 (N.Y. App. Div. 1984) (“[P]urchaser is charged with constructive notice of litigation if he [or she] fails to record the deed prior to the filing of the notice of pendency."); $c f$. id. at 381 (Magano and Eber, JJ., concurring) (discussing effects of notice of unrecorded interests and denial of "priority to the party who wins the race to record his deed or encumbrance, but does so with knowledge of an unrecorded interest"); $c f$. Plank, supra note 7 , at $455-56$ (discussing "ability to base priority on a filing that precedes attachment and perfection" in securities law).

243. Cf. Scheid, supra note 13, at 102 ("The recording acts promote the notoriety of land ownership and preserve the muniments of title by encouraging grantees to record their deeds.").

244. See Neslin v. Wells, 104 U.S. 428, 434 (1881) (surveying custom-to-duty development cases involving real property and title information issues). 
case could be said to have constructive notice, notice requirements are context-driven and when the computerization of land records "lightens for the purchaser the burden which existed only a few years ago," then "[w]hat in the past may have been considered a diligent search may no longer be so considered because of the ease of retrieving computerized information relevant to encumbrances on property." 245 If you make the technology, it will matter. ${ }^{246}$

Whether ripening into a custom over time (as so many other prudent real estate practices have before ${ }^{247}$ or perhaps by statutory mandate, it could become common and mandatory practice for all purchasers and real estate professionals to consult TINTS whenever making a purchase to see if any allegedly-prior claimants had posted and staked a claim to inquiry notice on the system. Of course, concomitantly, it should become customary for the rational purchaser to also post and stake their claim on the system even before the records office has their claim up. One advantage of TINTS is that the information could be uploaded immediately post-closing, drastically outpacing actual recording of title and filling the information void during gaps in recording time.

If a purchaser finds an adverse competing claim on TINTS, then a red flag goes up, and the law could recognize that the subsequent purchaser is now on inquiry notice and must conduct a reasonable investigation into the legitimacy of the possible competing claim before becoming entitled to seek the status of bona fide purchaser without notice. The most common type of inquiry notice trigger under the law is possession of the property by one other than the grantor, but inquiry notice is a broader category than those types of factual scenarios and also includes all situations where "a purchaser has actual or constructive knowledge of facts that would have led a reasonable person to inquire further" about possible title conflicts. ${ }^{248}$ A TINTS entry would satisfy as

245. First Citizens Nat'l Bank v. Sherwood, 817 A.2d 501, 505 (Pa. Super. Ct. 2003), rev'd on other grounds, 879 A.2d 178 (Pa. 2005).

246. Cf. Nestor M. Davidson, Standardization and Pluralism in Property Law, 61 VAND. L. REV. 1597, 1629 (2008) (describing "numerous technological and policy changes in the past half century that have lowered information costs relating to property transactions," including title insurance).

247. Neslin, 104 U.S. at 437-38 (discussing several precedents where "effect was given to the existence of a known custom, in creating an obligation").

248. 3 PALOMAR, supra note $13, \S 673$ (triggering inquiry notice by matters in the record as well as facts learned outside the record); see also Long John Silver's, Inc. v. Fiore, 386 A.2d 569, 573 (Pa. Super. Ct. 1978) (explaining where party admitted actual knowledge of prior purchaser claiming an interest in the property, duty to inquire attached where "subsequent purchaser could have learned of facts that may affect his title by inquiry of persons in possession or others who the purchaser reasonably believes know such facts"). 
such a trigger.

TINTS takes advantage of the power of inquiry notice, empowering first-in-time purchasers to immediately spark the suspicion, raise the red flag, and alert all other would-be purchasers that a claim is being made on the property and that record notice is on its way. Filing a notice in TINTS would put a literal "tint" on the title requiring any other purchaser to investigate the source and legitimacy of that tint. It operates like an early warning system about the possibility of contested title, with the goal of fitting such warnings into our understanding of what constitutes a reasonable inquiry and setting as a prerequisite that a TINTS entry can serve as inquiry notice only when a full investigation of the TINTS entry would otherwise provide one with all the information necessary to determine the legitimacy of the competing claim hinted at by the TINTS listing. ${ }^{249}$

As a quality control and verifiability mechanism, uploading parties might be required to upload further information - such as the executed contract of sale and deed-within a short period of time after the initial entry (perhaps 5 days) to provide more solid evidence of their claim and the failure to do so could make their initial posting expire and render it ineffective for providing notice. Further steps could be required to keep the posting on TINTS and might even work to encourage recording. For example, an individual with a TINTS claim could be required to upload to TINTS a stamped copy of the deed as-filed in the recording office within a certain period of time (perhaps 3 months) or, again, if he fails to do so and does not keep the claim fresh and updated with increasingly higher-quality information then the party's TINTS posting will expire, disappear, and become ineffective at providing any type of notice.

Of course, the problem with more robust inquiry notice triggering is that it may add inefficient delays or even thwart the completion of desirable property transactions. Some may worry that adding burdens to purchasers to discover information could have negative effects on the market for land-increasing the cost of acquisition to the point that it pushes some purchasers out or so that it otherwise unjustifiably distorts and inflates the price of property. ${ }^{250}$

249. One would expect that title standards would develop as well to help identify the duties and liabilities of lawyers and others in using TINTS and to influence the practice and behavior of those involved in issuing title opinions and otherwise searching for verification of title.

250. Korngold, Resolving, supra note 18, at 1564 (worrying about "chill[ing] future market transactions" and concluding that "the rules should not unfairly favor current owners over successor buyers and should not place excessive or irrational search burdens on potential future buyers"); but see id. at $1567 \mathrm{n} .190$ (arguing that inquiry notice might be out-dated and too expensive but seemingly limiting it to physical inspection-based inquiry notice and not necessarily inquiry notice 
And, there are potential risks of abuse in such a system that could themselves have market-disrupting effects. For example, the risk of a fraudulent filing on TINTS to disrupt the market or harm a competitor is real $^{251}$ - even if it is just to post for purposes of delaying a property transaction by a few days to gain some kind of competitive advantageand any full development of a system like TINTS would need to spend substantial time developing safeguards against such abuses. Any TINTS-like system would need to find ways to prohibit adding costs to property transfers by those who might simply file fraudulent claims of purchase inside TINTS to muck up or slow down someone else's ability to buy property, to delay an owner's ability to sell, or to extract extortion-like payments from those whose actions they might seek to block through TINTS. It is imperative that safeguards are in place to prevent TINTS-like systems from being used to facilitate fraud.

Certainly though, inquiry notice is not subject to a hair trigger, and rumor alone, for example, should not spark the duty to inquire; ${ }^{252}$ there should be ways to require a minimum level of detail and content for any TINTS posting to cross a legitimacy threshold. The parties uploading claims should be required to register with TINTS, including providing reliable contact information that can be used by a prospective buyer to conduct his inquiry. Failure to provide accurate information could also be deemed as a forfeiture of any claim of notice by this method. A fee structure could be included that would serve as means of receiving more reliable information and to deter fraudulent uploading of claims. The goal must be to fit TINTS within the scope, and subject to the same limitations, of what we define as the effort and diligence necessary to

that would be triggered by other methods like "questions raised by recorded documents, since that may not greatly expand the buyer's burden").

251. Professor Szypszak explains some of the motivations to engage in abuse of recording systems:

The increased availability of information in modern society presents an opportunity for those who wish to harm others through fraud, false claims, and annoyance. The threat to the real estate records is a serious part of this development, because the potential impact of a fraudulent or frivolous real estate filing can interfere with a transaction involving substantial investments, or impair someone's capacity to obtain credit . . Although the frivolous nature of these instruments is readily apparent, the instruments can nonetheless cause harm to the target by holding up a transaction or impairing credit while the instrument is investigated.

Szypszak, North Carolina, supra note 24, at 225-26; see also Szypszak, Real Estate Records, supra note 15, at 38 ("At common law someone whose property rights are harmed by false claims might have a cause of action for slander of title.").

252. 5 TIFFANY, supra note $14, \S 1285$ (explaining that for inquiry notice to be triggered, buyer must receive "information ... sufficient to furnish a basis for investigation, and a mere rumor or indefinite statement that there is an adverse claim is not sufficient to put one on inquiry"). 
conduct a reasonable inquiry.

Other safeguards might also be developed. For example, individuals might contract with sellers to incentivize sellers to upload the transactional information, adding more reliability and transparency. Such contracts might even include remedies for failure to comply with a TINTS uploading agreement term. The system could require both buyer and seller to upload before the posting goes public. There might be a requirement that the purchaser provide seller information before making an entry eligible for public posting. The company or government agency running TINTS might have individuals policing and verifying TINTS postings, including perhaps checking validity by contacting the previous owner/seller to get concurrence in information provided by the supposed purchaser and, if they do not concur, perhaps the posting is then pulled (or never posted). These and other possible safeguards should be brainstormed and responses to potential abuses developed in conjunction with the development of the system.

TINTS would give first-in-time buyers an additional opportunity to protect their interests to the property by providing additional information to the public sphere that should be accessible to would-be subsequent purchasers such that those subsequent purchasers will be on inquiry notice of a claim by the previous purchaser even before it is feasible to have all of the relevant information recorded and indexed in the local records office.

The purpose here is only to propose and outline the concept of one approach toward minimizing the potential for grantors selling to two or more individuals and getting away with it due to nemo dat exceptions. My hope is that ideas will be generated to make the TINTS idea operational, and that the presentation of the TINTS idea might spark other innovative proposals. On TINTS itself, future work is required to develop the full details of a model for effective implementation with appropriate safeguards against abuse.

TINTS addresses problems that are primarily exacerbated by the continuing predominance of paper-based recording offices (for searching, filing, and indexing). Perhaps the traditional land records system will give way over time (and hopefully more rapidly and uniformly) to universal electronic recording systems that might make something like TINTS unnecessary if the new electronic recording regime manages to make recording and searching capabilities essentially instantaneous, thereby eliminating the gaps that TINTS is designed to 
address. At present, jurisdictions across the country have demonstrated dramatically different dedications of resources to converting their offices to electronic recording. ${ }^{253}$ Until resource priorities change and a more robust and widespread push is advanced for electronic recording, gaps will remain in effective recording times which TINTS or other fixes must address.

In all of our efforts to innovate, we should have as a goal the minimization of barriers to the law's ability to say that one truly cannot sell what they have previously sold. Finding new and reliable ways to inject information into the marketplace so that fewer purchasers are blind to adverse claimants should be a primary objective. TINTS, or other innovations like it, can assist us in matching these nemo dat preferences with property law pragmatism.

253. See supra notes 239-241 and accompanying text. 


\section{CONCLUSION}

Most people think we live in a nemo dat world - where one can only sell as much as they have and that once they sell something to one person they cannot turn around and sell it again to someone else. As this Article illustrates, that nemo dat world is something that we strive for but that the law realizes is not realistically attainable. So, although nemo dat stands at the foundation of our property system, so too do a variety of other pragmatic values influence the development of property and title law, including those associated with fairness to innocent purchasers, our desires to motivate individuals to record and make public their claims to title, and our hopes to maximize the market-facilitating effects that our recording system provides. Therefore, exceptions to applying nemo dat must be made in the real property transfer system. We have to allow some bad actors to do dirty deeds by passing dirty deeds to subsequent purchasers and hope that we can contain that undesirable and destructive activity in other ways.

Nonetheless, fuller adherence to the nemo dat idea should be something that we strive toward - not by changing the nature of the protections available to innocent bona fide purchasers, but instead-by finding new ways to inject a higher degree of reliable, verifiable title information into the market and doing so at a more rapid rate. We should aim to closely approximate a nemo dat world. We should innovate in ways that help us best match our nemo dat preferences with the understanding that we must always account for the pragmatic needs of our property system if we wish that system to function well. 